\title{
Residential landscapes-Garden design, urban planning and social formation in Belgium ${ }^{\text {ts }}$
}

\author{
Bruno Notteboom \\ KU Leuven, Faculty of Architecture, Campus Ghent, Hoogstraat 51, 9000 Ghent
}

\section{A R T I C L E I N F O}

\section{Article history:}

Received 6 October 2016

Received in revised form 18 February 2017

Accepted 20 February 2017

Available online $\mathrm{xxx}$

\section{Keywords:}

Garden cities

Garden history

Popularization

Social formation

Urban planning

Vernacular gardens

\begin{abstract}
A B S T R A C T
This paper aims at providing a historical understanding of the role of gardens and green spaces in urbanization and urban planning, as well as in processes of social formation and social mobility that took place on the background of a changing spatial, socio-economical and political context in Belgium in the period 1889-1940. The research is based on a number of case studies, which represent different stages and themes in the evolution of garden design, urban planning and society: 1) vernacular versus designed gardens and landscapes; 2 ) the popularization of the garden and the development of a new framework for urban planning; 3) the garden city versus private arcadia and 4) modern garden design and the rise of the middle class (1930-1940). Through an analysis of designs and discourses of, amongst others, leading landscape architects/urban planners Louis Van der Swaelmen, Jules Buyssens and Jean Canneel-Claes, the paper exposes a number of ambiguities and tensions, for example between the 'vernacular garden' and the 'garden of the establishment' and between the deep-rooted dream of a privately owned house and garden, and attempts to create new social and spatial frameworks that surpass the individual lot. The paper concludes that these tensions can still be traced in the context in which landscape designers and urban planners work today. This historical awareness, however, can help them to set out strategic goals for the contemporary garden as a place of both production and consumption, and as a place where social identity is shaped.
\end{abstract}

(c) 2017 Elsevier GmbH. All rights reserved.

\section{Introduction}

The history of garden and landscape design in Belgium has only been fragmentarily explored thus far. The historical evolution of the Belgian territory in the nineteenth and twentieth centuries is extensively covered from the perspective of urban planning, focusing on post-war reconstruction, urban development and housing (Smets, 1977; Smets, 1985; Smets and Buls, 1995; De Meulder et al., 1999; Van Herck and Avermaete, 2006), infrastructure (DeBlock, 2011; Peleman, 2013; Van Acker, 2014) and economy (Ryckewaert, 2011). Also the role of urban nature and green spaces in urban policy since the nineteenth century has recently been studied, mostly from the perspective of urban history (Stynen, 2010; Tritsmans, 2014). However, there seems to be a gap between urban (planning) history on the one hand, and the history of garden and landscape design on the other, notwithstanding a number of first explorations (Imbert,

\footnotetext{
放 This article is part of a special feature entitled "Strategic gardens and gardening: Inviting a widened perspective on the values of private green space" published at the journal Urban Forestry \& Urban Greening 30C.

E-mail address: bruno.notteboom@uantwerpen.be
}

2009; Notteboom, 2009; Notteboom, 2012; Van Damme, 2013). While this has been explored in international literature (e.g. Treib, 2002; Haney, 2010), a reflection on the relationship between garden design, its larger urban socio-economical and political context and the discipline of urban planning in Belgium is still lacking.

Belgium is an exemplary case when studying the potential strategic value of gardens, and especially the vernacular garden. Historically, the social, cultural and economic meaning of the private family garden is inextricably linked to the history of urbanization and urban planning in Belgium. As will be outlined further in this paper, the particular historical evolution of the Belgian residential landscape is characterized by a high degree of private home (and garden) ownership and a relatively weak planning apparatus. The underrepresentation of larger-scale public commissions in the practice of many landscape and garden designers made it, in comparison to other European countries, difficult to 'leap the garden fence' towards collective or public commissions on a larger scale (Van Damme 2013). Hence, constructing social and cultural identity through the garden and gardening was in Belgium in the first place linked to the private garden. This paper has two aims: first, outlining how the ideas and practices related to - both vernacular and designed - gardens evolved in the context of urbanization and 
urban planning in Belgium in the pre-World War II era, and second, how social formation took place in the process.

I will argue that this history of both urban planning and social formation through the lens of the garden is not free from contradictions and ambiguities: from the end of the 19th century onwards, the history of urban planning has been marked by a number of attempts to develop residential landscapes that fulfilled the need of different collectivities on a scale that surpassed the individual lot, resulting in a balancing act between collective and public needs and the deep-rooted dream of the private house and garden. Also the construction and constant re-negotiation of social identity what Denis Cosgrove calls 'social formation' in his seminal book Social Formation and Symbolic Landscape (1998) - by means of gardens and landscapes is a complex process. It is as much related to domination and power relations as to social emancipation, and it is grounded in physical gardens and landscapes as well as their representation (Cosgrove, 1998; Mitchell, 2002). In the period under study, the dominance of the - essentially bourgeois (Fishman, 1989) - model of the private garden led to a process of identity-building among the working and upcoming middle classes (in garden as well as in dwelling culture) that was largely based on a concept of social mobility of the population through the imitation of the higher classes (for a detailed characterization of the distinct social classes, see Bourdieu, 1979). Nevertheless, I will follow the argument that this process became much more complex in the early twentieth century (De Caigny, 2010), as new ideas on the socio-economic organization of society, political constellations and cultural references enter the fields of urban planning and landscape/garden design.

\section{Material and methods}

The paper is based on qualitative research on a number of historical case studies that deal with the above-described dynamics between the private and the public/collective in landscape architecture and urban planning, and the process of social formation that is related to it. The cases deal with evolutions on the long term, as well as specific pivotal moments in history, resulting in a reading of history that is at once diachronic and synchronic. This qualitative research method thus allows us to formulate a number of general perceptions that surpass the specific case (Flyvbjerg, 2006). The timeframe of the case studies is delineated on the one end by 1889 , the date of the first Belgian Housing Act, which stimulated the possession of a privately owned house with a garden for large parts of the population, and on the other end by 1940, the start of World War II. This period witnessed a number of important socio-economic, cultural and political evolutions, which thoroughly affected the discipline of the garden and landscape design as well as that of urban planning (Notteboom, 2009; Notteboom and Peleman, 2012). In the course of the early twentieth century, urban planning evolved from a discipline that aimed at a sanitation and embellishment of the city, mainly from a hygienistic and aesthetic perspective reassuring the privileges of the higher classes (the nobility and the bourgeoisie), to a discipline that had the ambition to form a public planning apparatus with an emancipatory character for society as a whole (Uyttenhove, 2003). This new disciplinary context provided a fertile ground for new ideas on the collective and public role of gardens and urban green spaces. The growing emancipation of the workers' class and the rise of a middle class, made the private house and garden accessible for an increasing part of the population, laying the foundation for complex processes of social positioning and identity building (Notteboom, 2009; Notteboom, 2012; De Caigny, 2010).

The reading of the period $1889-1940$ is in this paper subdivided according to four key moments that represent changes in the discipline and policy of urban planning and landscape/garden design, as well as in the socio-cultural, economic and political context in which they took place. These key moments should not be considered as strict demarcations: they rather serve as stepping stones to address disciplinary and societal evolutions and themes that are at play throughout the whole period under study. In order to grasp the complexity of this evolution, different, often conflicting, discourses and practices of each periods are touched upon, outlining the parallel occurrence of both vernacular and designed, private and collective residential landscapes, and the mechanisms of social exclusion, emancipation and positioning involved.

The first moment, the 1889 Housing Act, marks the start of the democratization of homeownership and a large-scale, seemingly unplanned development of the Belgian countryside into a privatized residential landscape. This is paired, however, with the discussion of a number of examples of designed landscapes whose ambitions to surpass the individual lot serve different types of communities. The second moment, the project of a model house for workers in 1910 and the subsequent foundation of the association Le Nouveau Jardin Pittoresque in 1913, allows us to uncover a network of professionals of various backgrounds, as well as an amalgam of discourses of ideas on the role of the garden in society. It also leads to a pivotal moment in the discipline of urban planning, as it laid the foundation of the ideas of architect/urban planner Louis Van der Swaelmen and.his theory on urban planning. The third key moment is the Conference for the Reconstruction of Belgium of 1920, in which the Union des Ville opted for the model of the garden city for collective housing. At the same time, we will outline, the dream of the private house and garden as a means of social positioning remains a dominant socio-cultural and economic force, as illustrated by the work and discourse of landscape architect Jules Buyssens in the post-war context of Le Nouveau Jardin Pittoresque. A fourth key moment is the introduction of the 'functional' garden by landscape designer and urban planner Jean-Canneel Claes' in the 1930s, that sheds a light on the changing role of the garden and green space in the modernist idiom and its attempt to provide an alternative for the petit bourgeois garden. By way of conclusion, the results of the research are further discussed in the light of the objectives formulated in the introduction. The historical research is also put in perspective of possible strategic perspectives for gardens today.

\section{Results}

\subsection{Landscapes of labor and leisure. Vernacular and designed gardens and landscapes at the turn of the 19th century}

\subsubsection{Private homeownership as a cornerstone of urbanization}

'The ugliest country in the world', is what modernist architect/Renaat Braem called Belgium in 1968, and also: 'a patchwork, stitched together by a madman' (Braem, 1968). It has often been observed that Belgian landscape seems to lack any spatial design or sense of aesthetics, a vernacular landscape that seems to be filled in randomly according to the need of its inhabitants. This laissez-faire attitude and dispersed settlement pattern are however the result of a specific socio-economical and political context that accelerated this dispersal in the course of the nineteenth century (De Meulder et al., 1999; DeBlock, 2011; Peleman, 2013; Van Acker, 2014). Territorial spread was accommodated by a dense and finegrained railway system, which became accessible for all parts of the population by a system of cheap railway tickets for employees (De Block and Polasky, 2011). The unification of the labor market was combined with a liberalization of the land market, with as pivotal moment the first Belgian Housing Act of 1889. This law stimulated the individual ownership of new houses with gardens in the countryside, through a system of subsidized loans, which is 
still the cornerstone of Belgian housing policy today. The law was by many liberal reformers stigmatized as the Catholic law for the countryside: concentration of workers in the cities - and hence social unrest - was kept under control by keeping them 'under the church tower'. The financial and emotional attachment to a privately owned house and garden went hand in hand with the promotion of the family as the cornerstone of society (De Caigny, 2010; De Decker, 2011).

This territorial spread and high degree of home-ownership lead to the development of a vernacular type of house and garden: a terraced house - actually an urban house type - on the long, narrow lot, that was built almost anywhere along the existing roads. The backyard was a non-representative private space (representation was the function of the façade), a place for the typically Belgian 'liberated nonchalance' (De Meulder et al., 1999) and could be filled in according to the wishes of the home-owner: it provided enough space for an extension of the house (typically kitchens, bathrooms and storage sheds were added later on), space for domestic activities as drying laundry, but also (semi-)rural activities such as vegetable and fruit garden, the breeding of chickens or small kettle etc. (Fig. 1) This semi-urban/semi-rural housing type accommodated a hybrid way of life that was injected in the countryside and allowed families to make a living of factory work combined noncommercial agriculture (De Caigny, 2010). This kind of vernacular gardens were determined by functionality and work, rather than by aesthetic considerations (Jackson, 1994; Conan, 1999). The urbanization within the existing rural road system, creating the typical Belgian vernacular landscape, was a territorial project determined by economy and infrastructure, rather than a landscape project determined by spatial design or a shared economic or socio-cultural collectivity: it could be realized parcel by parcel, without having to worry what happens on the other side of the garden fence.

\subsubsection{Designed residential landscapes}

At the beginning of the twentieth century, in a number of designed residential landscapes, gardens and green infrastructure that surpassed the individual lot figured as an expression of a form of collectivity, based on leisure and aesthetic pleasure. Introduced by King Leopold II to a number of real estate companies, the German architect Joseph Stübben drew the allotment plans for coastal villa resorts, for example in Knokke-Zoute (dating from 1904) (Karnau, 1996; De Meulder et al., 1999). The spatial unity in this villa allotment filled with cottages was mainly accomplished by the design of the gardens and the green infrastructure. A strict regulation of hedges and plantings, as well as a smart grouping of dwellings (sometimes two or three under one roof give the impression of one large villa) guaranteed the image of a villa landscape. (Figs. 2 and 3 ) This combination of regulation and high-maintenance design was very successful in creating a landscape of exclusion, intended for the higher classes. Far away from the city and industrial centers, this landscape didn't refer to labor in any way, as was also the case in similar allotments in Europe and the US at the time (Clapson, 2003; Hayden, 2004). This image of leisure was reinforced in the media in which the lots were advertised: although these allotments privatized and urbanized the landscape, the image of a cottage in an untouched natural dune landscape was prominent in the publicity campaign in popular magazines as Le Home until far in the 1920s. (Fig. 4) This kind of images exposes the ambiguous nature of Knokke-Zoute: it's 'collectiveness' is aesthetic rather than giving rise to an inclusive community. As Robert Fishman (1989) argues, this type of residential enclaves can be read as a 'collective effort to lead a private life'.

These designed leisure landscapes and gardens seem to differ radically from the vernacular gardens defined by functionality and labor described above.Both met in the designs for the mining villages of Waterschei and Winterslag, based on the garden city principle and constructed in the same period as Knokke-Zoute (Loeckx et al., 1991). (Figs. 5 and 6) The landscaping followed roughly the same principles as the coastal resorts designed by Stübben,. while introducing more collective and public green spaces around which the workers' houses were grouped. The engineers lived in villas in their own garden on the edge of the garden city, Labor was not excluded from this residential landscape, and added to its complexity: apart from the mining installations at border of this residential landscape, the vernacular garden was introduced within this formal framework: invisible from the formal front, the large back yards were intended for growing vegetables, that over time transformed into an amalgam of annexes, garages, sheds, storage places etc. (Smets, 1977; De Meulder et al., 1999). Knokke-Zoute and Winterslag/Waterschei were both created as the anti-image of an urban environment, however with an outspoken different goal: respectively creating an exclusive residential environment and keeping social unrest under control. Nevertheless, the medium was the same: a picturesque residential landscape in which social stratification was the result of garden and landscape design.

\subsection{From the popularization of the garden to a new framework for urban planning}

\subsubsection{A model house for workers and the "New picturesque garden'}

In contrast to Great-Britain and the US, where suburbanization took off earlier (Clapson, 2003; Hayden, 2004), the freestanding pavilion-typed suburban house was in Belgium a privilege for the bourgeoisie until far into the interwar era (De Caigny, 2010). Nevertheless, the design for a model house and garden for workers, displayed at the World's Fair in Brussels in 1910, illustrates that the model of the cottage-like house standing in it's own garden although not affordable - was entering the dreams and aspirations of the lower classes as well (Smets, 1977). (Fig. 7) The garden of the model house was designed by Jules Buyssens, a professional architect, commercial horticulturalist and inspector of the City of Brussels plantation service. What is striking in the drawing of the model garden, is that it doesn't refer in any way to the vernacular character of a garden of a workers' house: it actually shows a rather formal front yard cornered by conifers and a flower bed closer to the house, without any trace of a kitchen garden. In 1913, in the wake of the exhibition of this model house, Jules Buyssens founded together with André Van Billoen, the director of the credit company that commissioned the design, Le Nouveau Jardin Pittoresque ('The New Picturesque Garden', further LNJP). It was described as a 'national association for the renovation and the popularization of garden art' (Van Billoen, 1913: 6). (Fig. 8) The association started out as one of the first attempts to educate and emancipate the workers' class by means of the garden (Notteboom, 2012). In its program statement it announced its intention to be active in the field of 'The social and moral role of the garden - The affinity between the evolution of the garden and that of morals - Influence of the contact with and studies of plants on the happiness and the formation of the spirit - Garden cities, parks and public promenades Workers' gardens, school gardens and gardens for children' (Anon., 1914a: 57). This was traditionally the terrain of the allotment garden movement (Segers and Van Molle, 2007), and from the interwar era onwards, well-organized catholic and socialist workers' movements. (De Caigny, 2010). Nevertheless, LNJP is an interesting case because it brings together an amalgam of ideas on gardens and nature from different disciplines that would later on find their way to urban planning. It also gives an insight in the changing role of the garden in the complexity and ambiguity of processes of social identity building among the bourgeoisie, the workers' class and the 

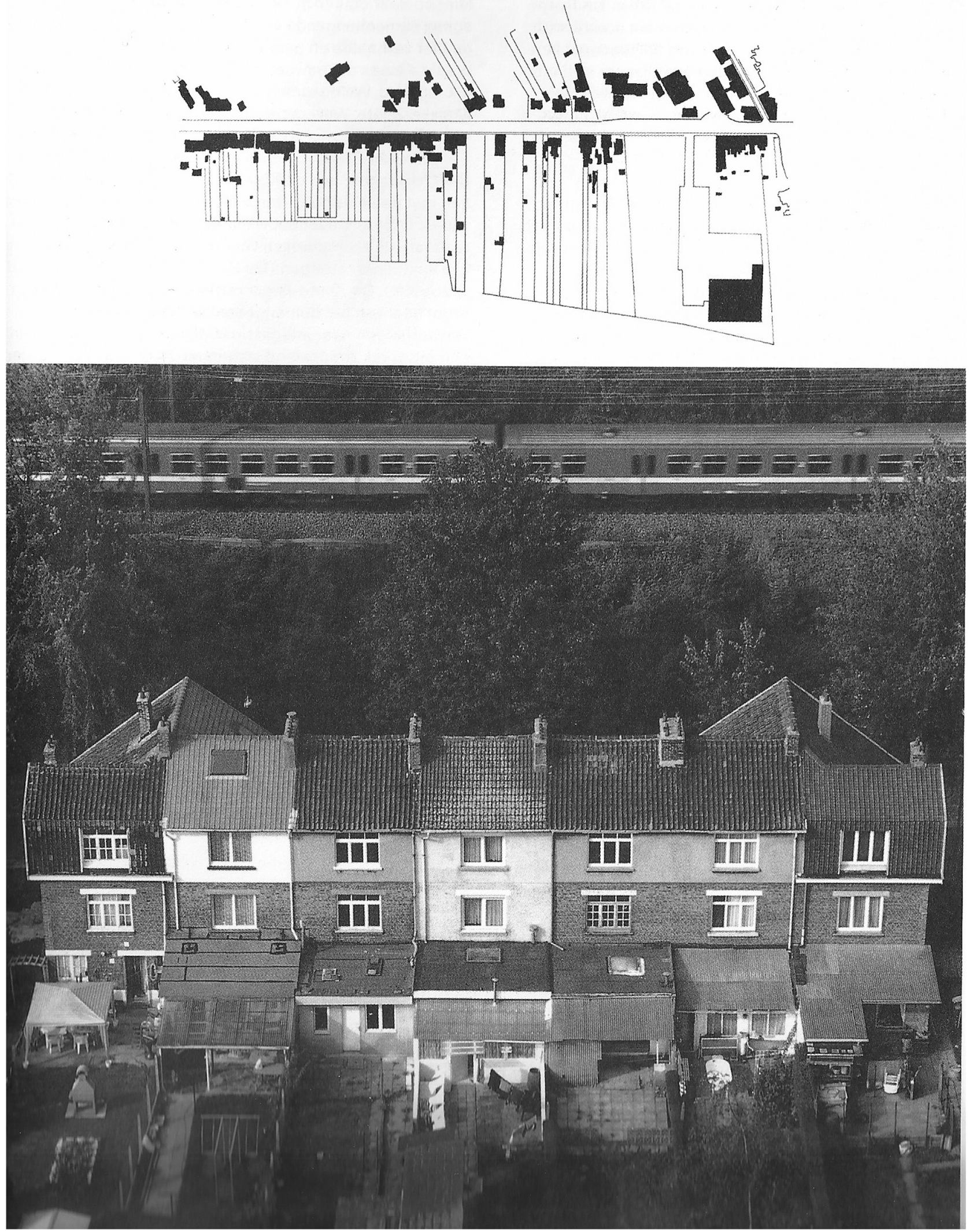

Fig. 1. The vernacular garden. 


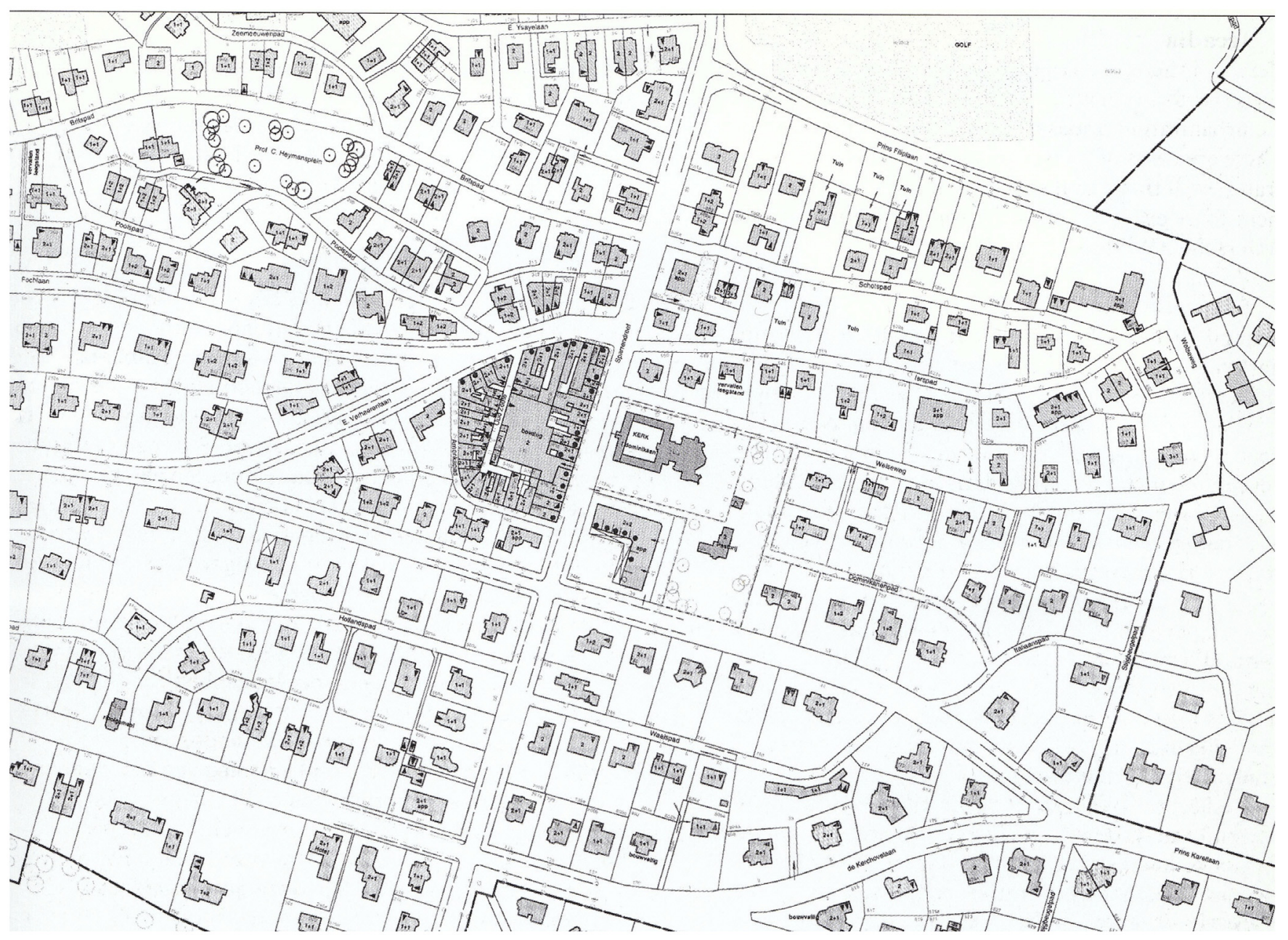

Source: De Meulder et al. (1999)

Fig. 2. Allotment plan of Knokke-Zoute.

middle class and how cultural concepts and symbols move along social classes.

Aesthetic considerations about gardens and gardening were before the World War I the terrain of the nobility and bourgeoisie, which were Jules Buyssens' main clientele. However, the model of the 'natural' or 'wild' garden as an alternative for the 'false imitation of nature' (Van der Swaelmen 1913a; Van Billoen, 1913) was not only underpinned by aesthetic, but also by societal concerns. Although English garden magazines, and the work of Gertrude Jekyll and William Robinson were explicit references, the 'return to nature' idea also echoed German discourses on the Naturgarten (Wolschke-Bulmahn, 2004) and the influential Lebensreform movement that propagated the experience of nature in processes of social emancipation (Krabbe, 2001). Jean Massart, who took care of the scientific grounding of Le Nouveau Jardin Pittoresque, and whose images of natural landscapes served as a model in its journal, was one of the protagonists of the popularization of botanical science in Belgium (Notteboom, 2009). He was involved in 'sociobiological' research with socialist foreman Emile Vandervelde at the end of the nineteenth century, which expanded his interest in the interaction between the organism and its environment (what we now call ecology) to the social realm (Massart and Vandervelde, 1895) (Fig. 9).

\subsubsection{Préliminaires d'Art Civique: a theory for urban planning}

This interest in the natural milieu, as well as the idea of a social role of gardens and landscapes, found their way to the young discipline of urban planning through the work of landscape architect/urban planner Louis Van der Swaelmen during World War I (Stynen, 1979). It was mainly Van der Swaelmen who stressed the topic of workers' gardens and garden cities in LNJP in the pre-war years. Spending the war in exile in Holland, he wrote Préliminaires d'Art Civique, which was both a guide for the reconstruction of the country as well as a handbook for urban planning in general (Van der Swaelmen, 1916a). It incorporated British concepts of garden cities, town planning and survey, but also leaned on his own ideas developed during his career as a landscape architect before the war. In the book, Van der Swaelmen proposed a twofold solution to solve the crisis of the modern city and the unbridled urbanization of the Belgian territory: first, to develop a system of urban planning based on an objective and scientific survey, and second, to 'realize the superior harmonies and ideals between things of nature and the creations of Man'(Van der Swaelmen, 1916: 100). Later, in the framework of the Société des Urbanistes Belges (Belgian Society of Urban Planners), he launched the term 'the socio-biology' of cities (Bodson et al., 1919). As a way of dealing with the 'dispersed urbanization of the Belgian territory and the ubiquitious presence of the 'degenerated urban house type', Van der Swaelmen suggested to adapt the settlement structure to the characteristics of the site and the region, for example by using local plant species, an idea he had already promoted on the 1913 Horticultural Conference in Ghent. (Van der Swaelmen, 1913b). There was a direct line between his writings on landscape architecture and his theory on urban planning. His conception of the wild garden as a garden that 


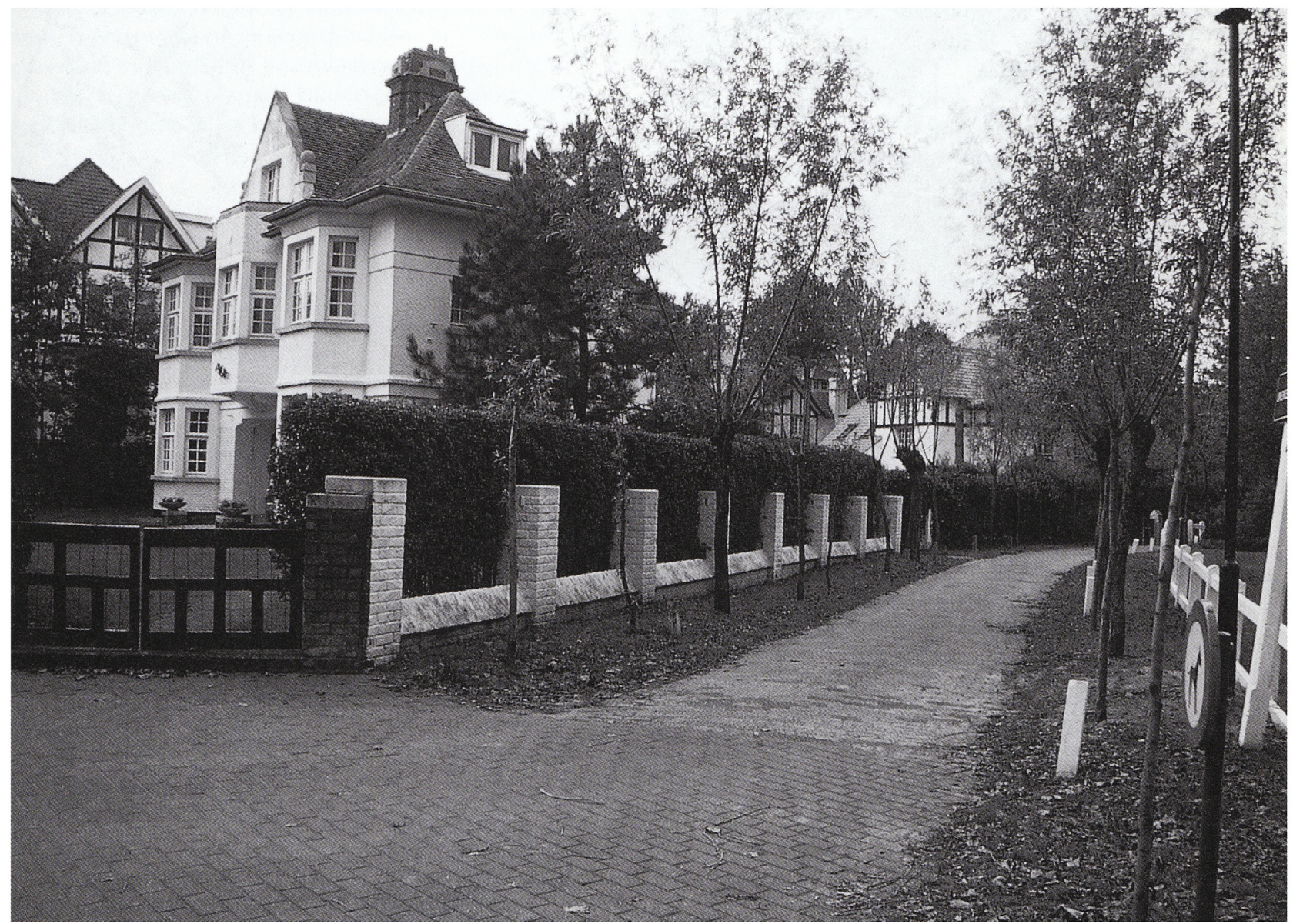

Fig. 3. Gardens and paths, Knokke-Zoute. Photograph by the author.

was anchored in 'the physiognomic character of the landscape in the region' (Van der Swaelmen, 1916b) was echoed in his proposal in Préliminaires d'Art Civique to further ground planning in the natural characteristics the territory and to anchor urbanization where possible in this 'physionomy', aided by the scientific geobotanical classification of the territory of Jean Massart (Massart, 1910; Van der Swaelmen, 1916a).

\subsection{The garden city versus private arcadia}

\subsubsection{Garden cities for 'a new social order'}

Although Préliminaires d'Art Civique didn't lead to a new planning instruments on the short term - the first law on urban planning in Belgium was only voted in 1962 (Lauwers and Coppens, 2012) - Van der Swaelmen could test his theory in the design of a number of garden cities in the 1920s, mostly around Brussels (Smets, 1977; Stynen, 1979). The plan to develop a ring of garden cities around Brussels, which was only partially realized, was for Van der Swaelmen the way to methodically expand the city in an 'organic' way (Van der Swaelmen, 1925). At the conference for the reconstruction of Belgium of 1920, the Union des Villes decided to evacuate workers' housing from the sphere of speculation, by opting for the model of the garden city, which would be realized by the Nationale Maatschappij voor Goedkope Woningen en Woonvertrekken (National Association for Cheap Houses and Rooms) (Smets, 1977). This umbrella organization of social (rental) housing companies was lead by socialist senator Émile Vinck and in contrast to the case of the corporate garden cities of Waterschei and Winterslag realized by private capital, urban planning and landscape design served 'the creation of the material environment for a new social order' (Verwilghen, 1919: 101).

The garden city in which the spatial and societal concepts of Van der Swaelmen are best expressed is Le Logis-Floréal, which actually consists of two connected garden cities on a hilly terrain. (Figs. 10 and 11) The most striking feature of the plan is its heterogeneous character, caused by the topography: 'The road network was, to remain organic, almost dictated by the conditions of the terrain,' which lead to a 'spontaneous, unsearched, picturesque layout.' (Van der Swaelmen, 1925: 4). The constellation of front and back yards, public green spaces and a system of paths that lead across the garden city turned it into a residential landscape that surpassed the scale of the individual lot. It provided not only a less space-consuming alternative to the dispersed vernacular development along the existing road infrastructure since the 19th century, it also gave shape to a collectivity. Social formation was determined by a unifying ambition in which the garden complex had a symbolic meaning. As the founder of the rental cooperative La Cité Moderne put it, the creation of a garden city consisted of on the one hand 'a harmonization of houses and gardens', and on the other hand the rapprochement of individuals, making them aware of their civil duties (...) and fostering solidarity ' (Rens, 1925; Smets, 1977: 126). However, this was only partially realized: as they addressed only (social) tenants, in reality they created rather spatially and socially segregated communities instead of a new form of society (Smets, 1977).,Solidarity was also paired with social control: some local housing companies regulated the height of the hedges between gardens in order to guarantee visual transparency in the garden complex (De Caigny, 2010). As this kind of dwelling prac- 


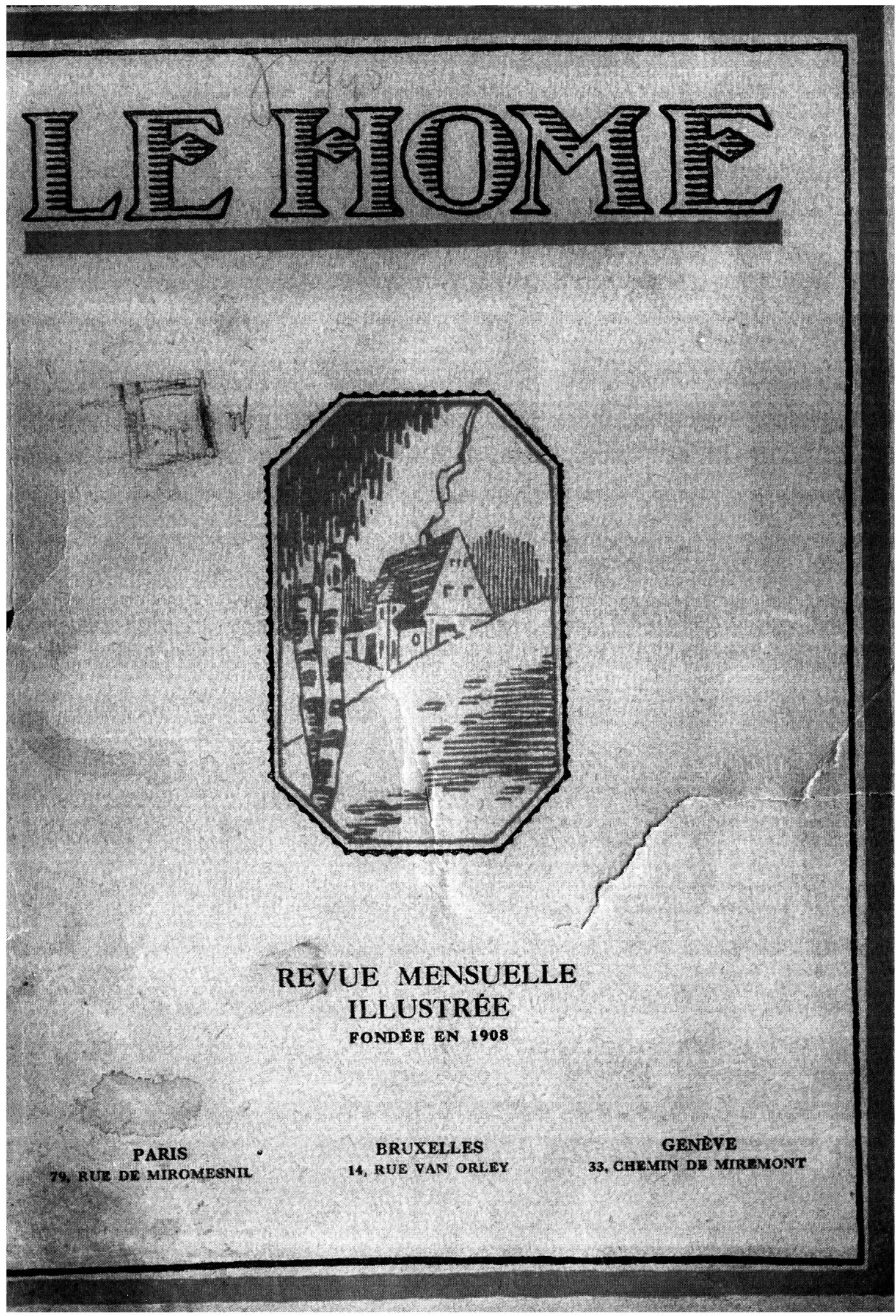

Fig. 4. Cover of Le Home, 1923.

tices went against the grain of deep-rooted socio-cultural image of the vernacular urbanization based on the accumulation of private houses and gardens, garden cities remained an anomaly in the Belgian residential landscape.

\subsubsection{The garden as status symbol: social imitation}

Van der Swaelmen's colleagues who remained active in LNJP, and especially Jules Buyssens, addressed the other side of the socio-economic spectrum. The examples of gardens he provided 


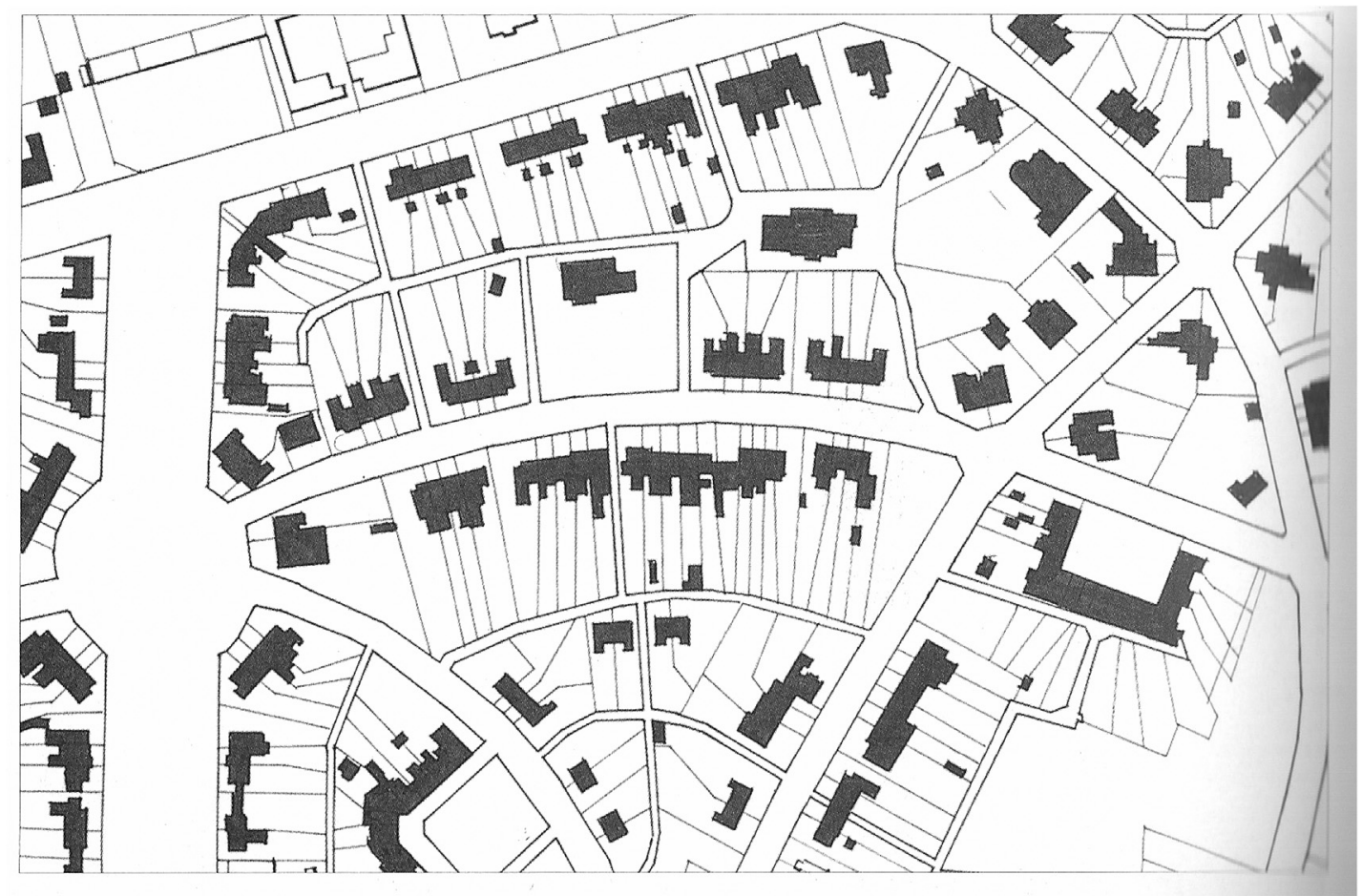

Fig. 5. Allotment plan of Winterslag De Meulder et al. (1999).

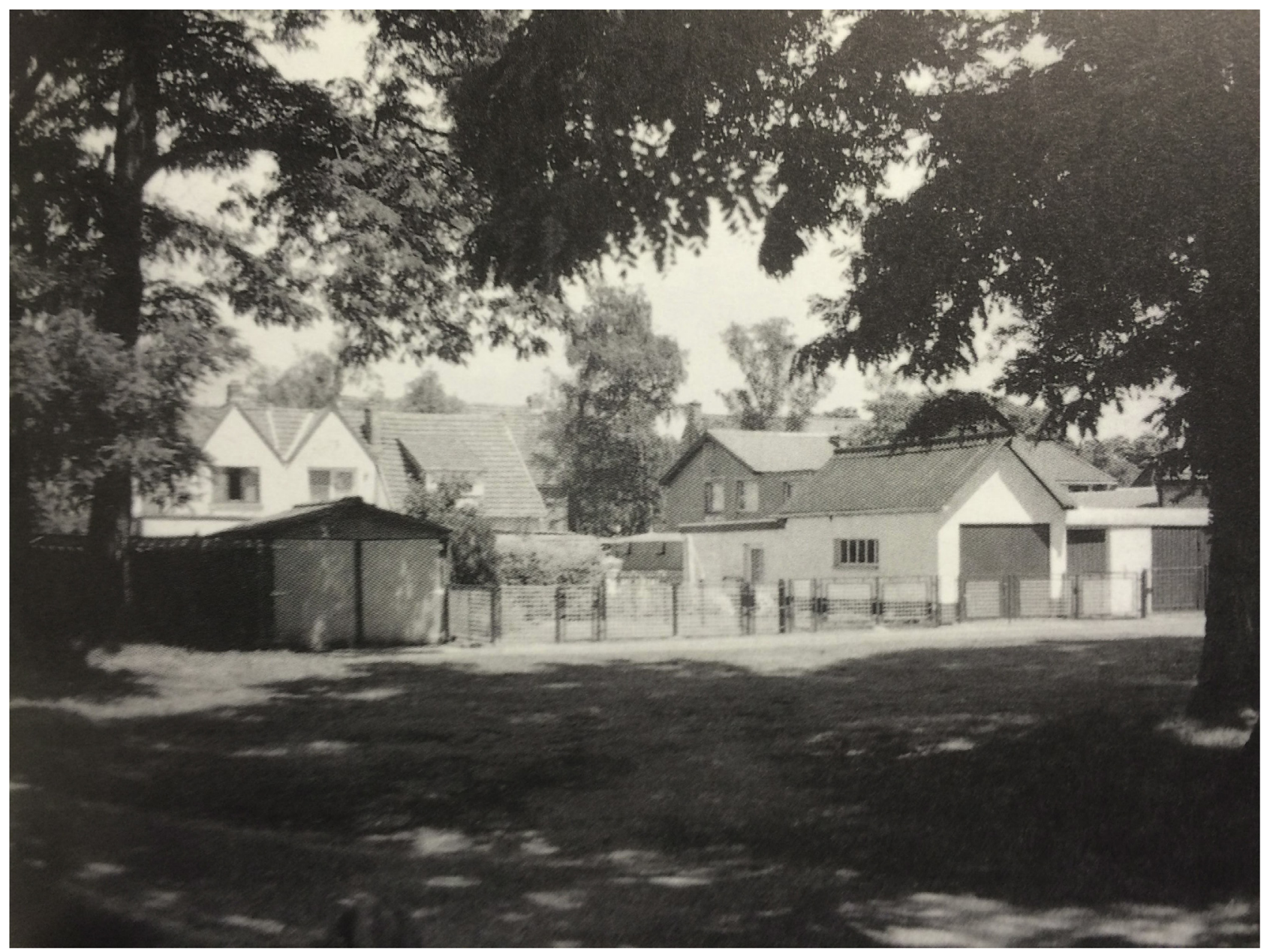

Fig. 6. Winterslag: vernacular gardens. Photograph by the author. 


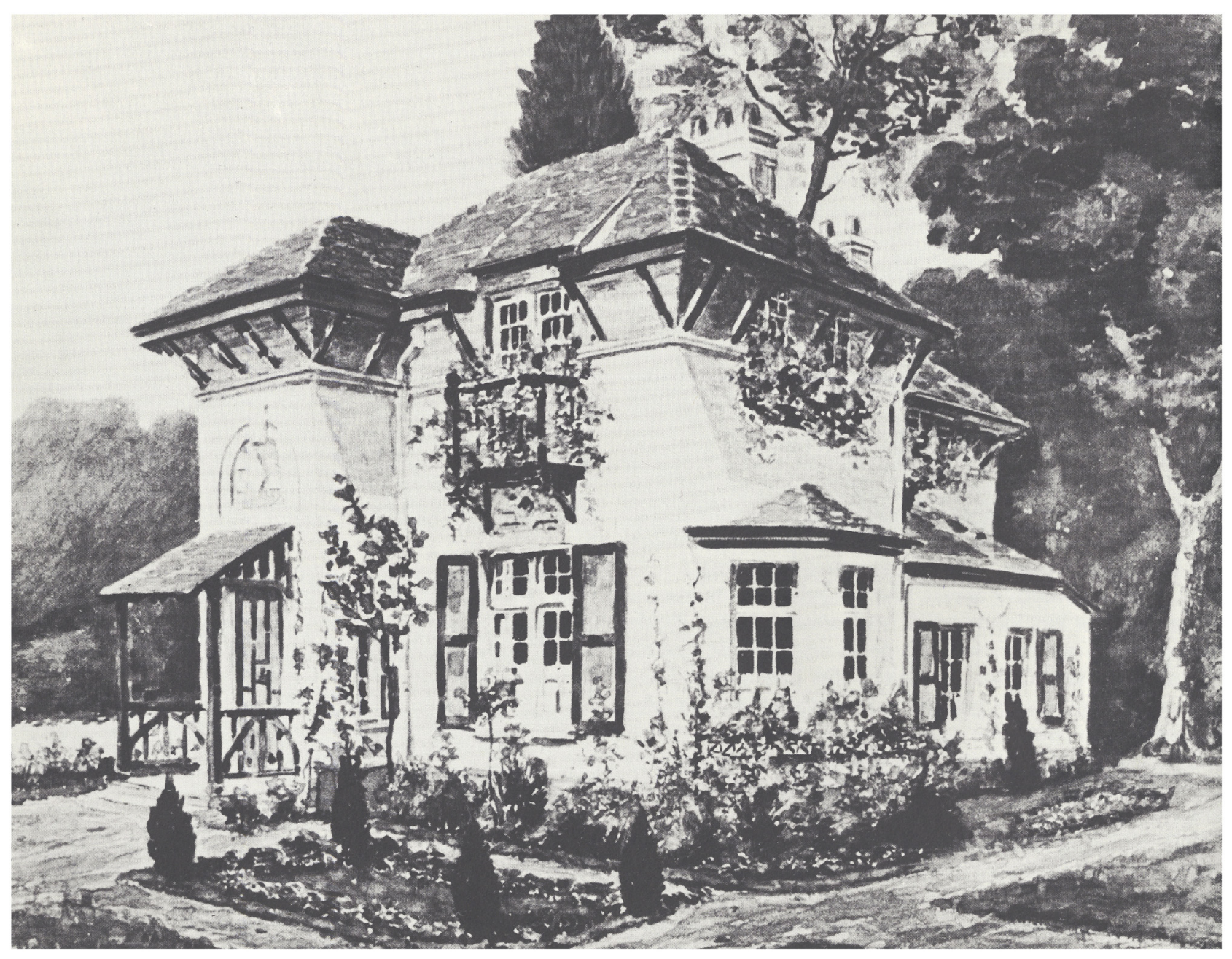

Fig. 7. Model house and garden for at the 1910 World Exhibition (Smets 1977).

in the periodical Le Nouveau Jardin Pittoresque in the 1920s and 1930s, often artificial water or rock gardens that stood actually far from the idea of the wild garden promoted before the war, were labor-intensive and expensive and needed the aid of a trained horticulturalist and a landscape architect. Jules Buyssens was both, and LNJP functioned as much as a promotional vehicle for his practice than as a magazine that informed about garden design and gardening. The members' list published in the first issue of the periodical reveals that the association counted, apart from landscape architects and horticulturalist, mostly aristocrats and members of the higher bourgeoisie (Anon., 1914b), which evolved in the interwar era to the higher regions of the middle class, but certainly not to the working class.

In LNJP, the garden played an important role in the creation of social, cultural and gender identity. Buyssens gathered a community around the association by organizing flower shows and lectures on subjects as the evolution of the art of gardening, jardins alpins or botany, as well as excursions in Belgium and abroad (Buyssens, 1925). Although this kind of activities were a way for women to participate in the public sphere, membership of LNJP was mainly a means to position oneself on the social ladder. (Fig. 12) This was paired with a process of social imitation. The members' journal provided examples of how the scènes paysagères of the nineteenth-century aristocratic domains could be simulated in the context of the smaller, often (sub)urban garden. (Fig. 13) In line with the 'gardenesque' in England, the 'new picturesque' garden was an instrument that allowed the lower bourgeoisie to appropriate cultural symbols of the higher class (Fishman, 1989). This was very much anchored in the model of the private garden and hence, Jules Buyssens, who was also inspector of the City of Brussels plantation service, rarely touched upon issues related to public green spaces the association's journal. The garden was conceived as a private arcadia with no ambition to contribute to the world outside of the garden fence.

\subsection{Modern garden design and the rise of the middle class}

\subsubsection{The 'functional garden'}

The primacy of the private house and garden as a cornerstone of Belgian dwelling culture had been questioned by the garden city movement in the 1920s., The years 1929-1930 marked an another paradigmatic shift in the debate on collective housing in modern architecture and urban planning Belgium and internationally.Van der Swaelmen, who thaught both urban planning and landscape design at the ISAD (Insitut Supérieur des Arts Décoratifs, Superior Institute for Decorative Arts) in La Cambre in Brussels, the hotbed of Belgian modernism, died in 1929. In 1930, on the CIAM (Congrès Internationaux d'Architecture Moderne, International Conferences on Modern Architecture) conference in Brussels, where Le Corbusier presented La Ville Radieuse, and the Belgian architect Victor Bourgeois his plans for Le Nouveau Bruxelles, the concept of the garden city was exchanged for that of the highrise in a green set- 


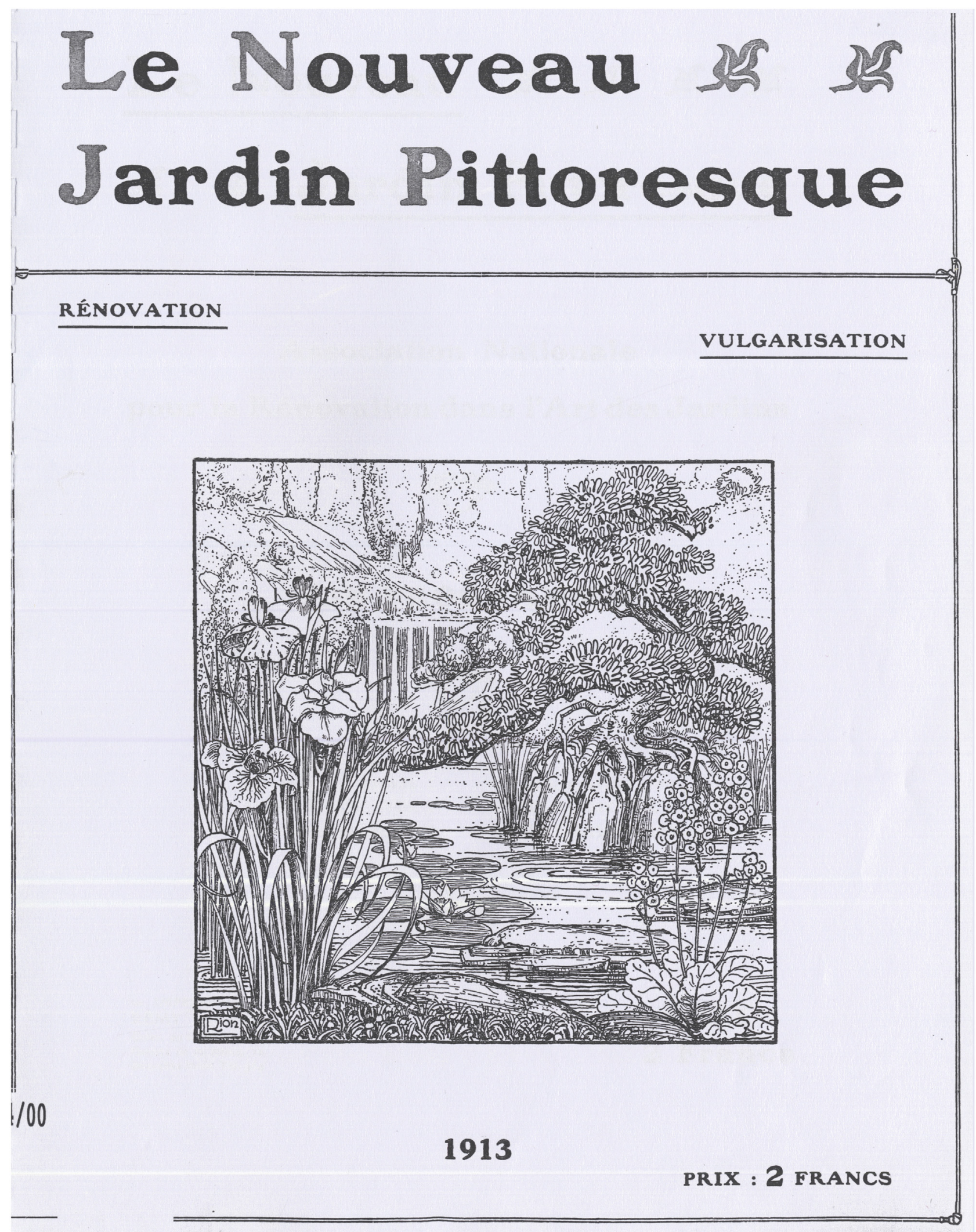

Fig. 8. Cover of the first issue of Le Nouveau Jardin Pittoresque, 1914.

ting (Strauven, 2015). (Fig. 14) This new conception of the city changed the relation between the dwelling and the garden thoroughly: instead of staging the contact between man and nature in the private garden, the dwelling - at least in the opinion of 'hard- core' modernists as Le Corbusier - would be lifted above a collective landscape and only visually relate to it (Colomina, 2002).

However, realizations of this kind of large-scale highrise developments in Belgium remained rare, even if the installation of 

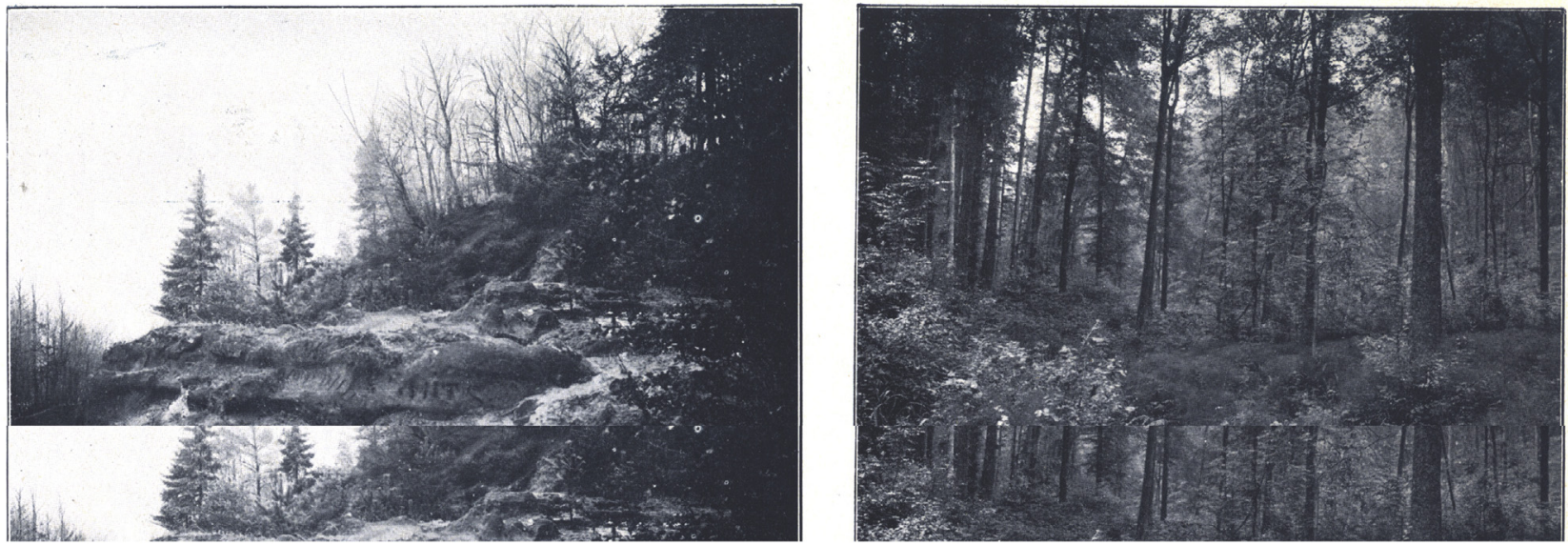

Fig. 9. Images of botanist Jean Massart serving as examples for the 'new picturesque' garden. Source: Le Nouveau Jardin Pittoresque, Association Nationale, 1913.



Fig. 10. Plan Le Logis-Floréal. Source: La Cité, 1929. 


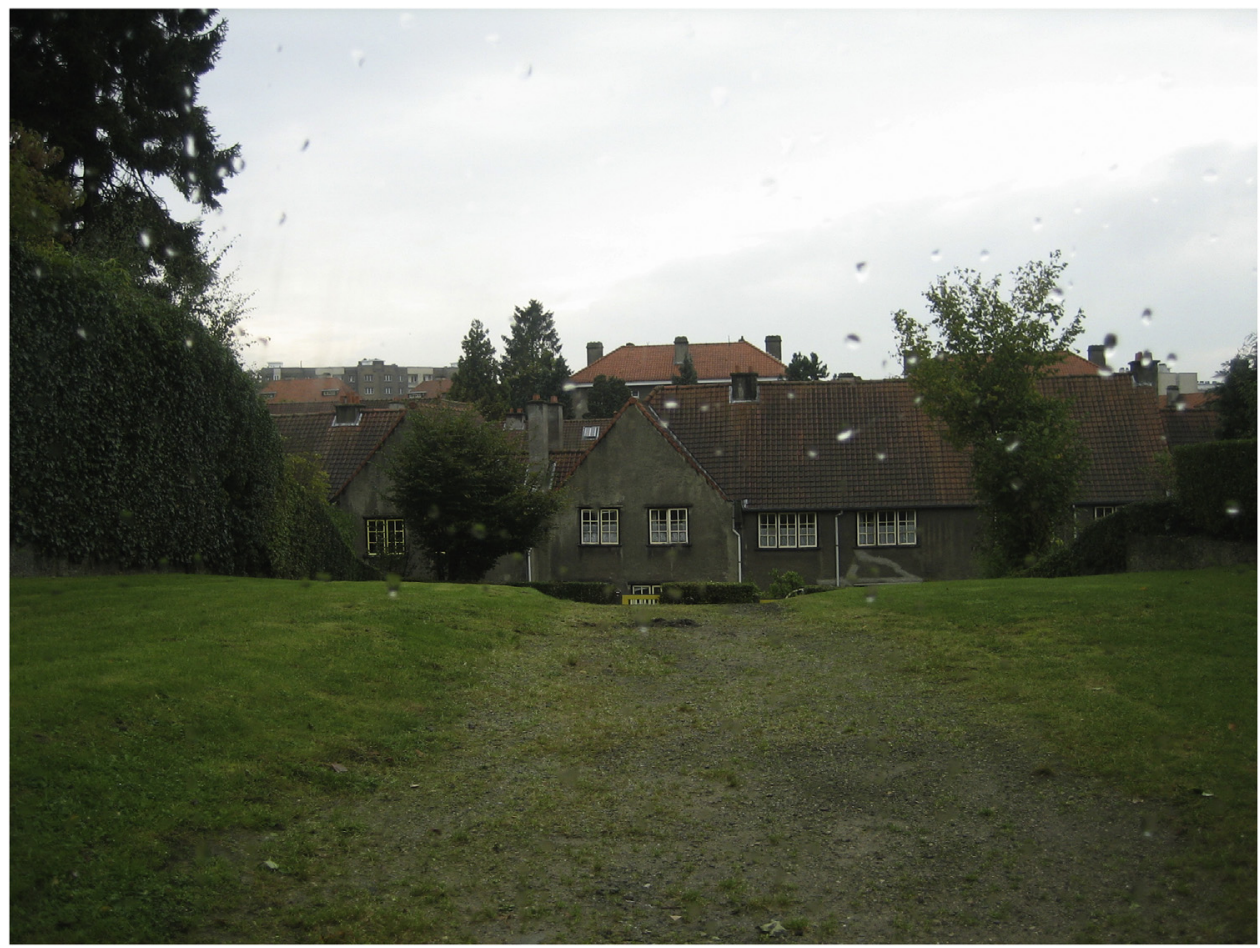

Fig. 11. Le Logis-Floréal: dwellings integrated in the landscape. Photograph of the author.

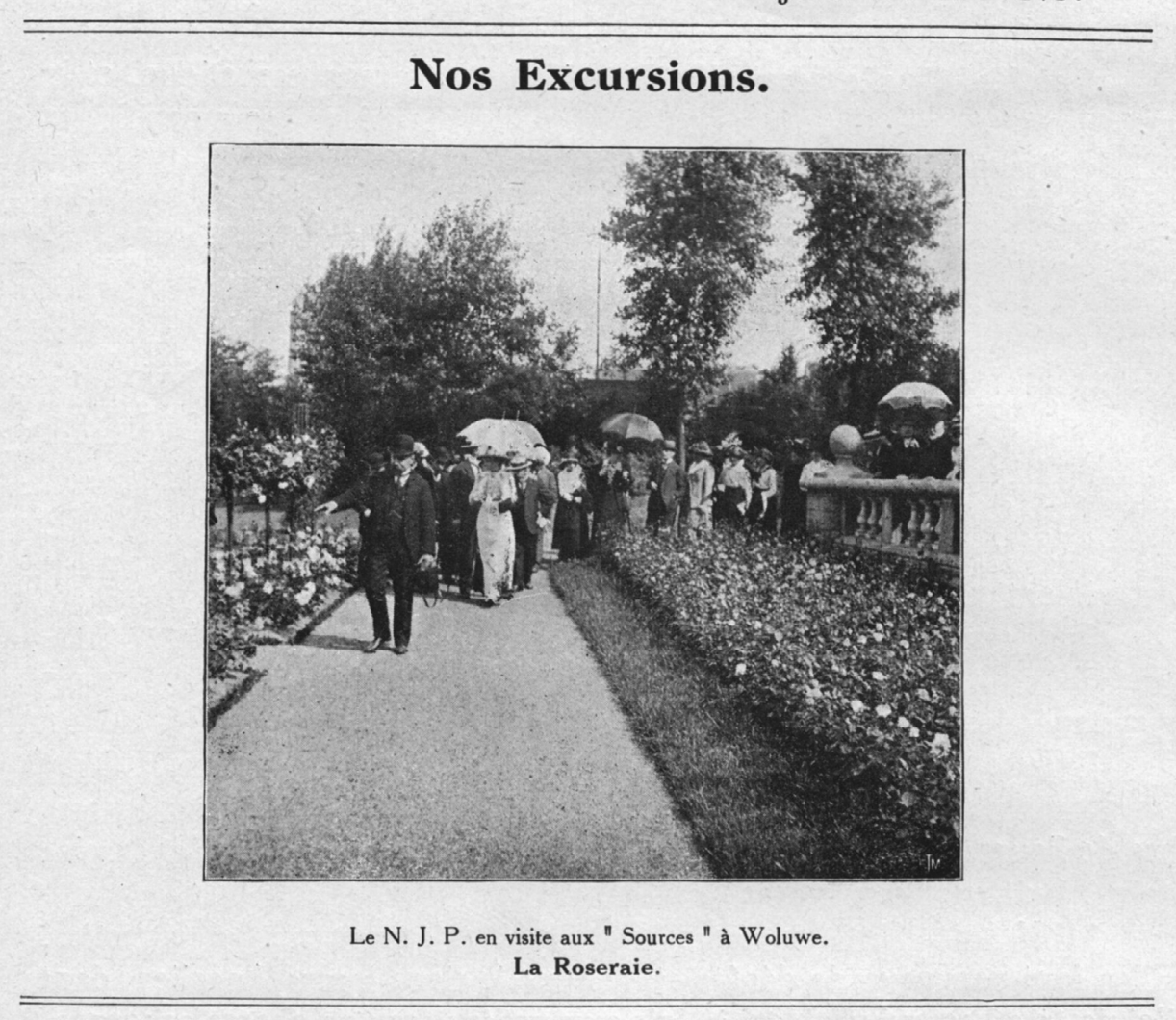

Fig. 12. An excursion organized by Le Nouveau Jardin Pittoresque. Source: Le Nouveau Jardin Pittoresque, 1923.

socialist Hendrik De Man as Minister of Public Works in 1935 held the promise of a planning apparatus that would surpass local and private interests (Vinck, 1939).,The actual production of the vernacular residential landscape remained anchored in the reality of a dispersed settlement pattern and the primacy of the private house and garden. Modernist (mostly leftist) architects were in reality confined to commissions of single family houses by 'enlightend' commissioners who were interested in avant-garde design (Van 
Scirpus, Thalia, Saururus, Typha, etc... Pour ces plantes, il faudra donc ménager des espaces de terre submergée.
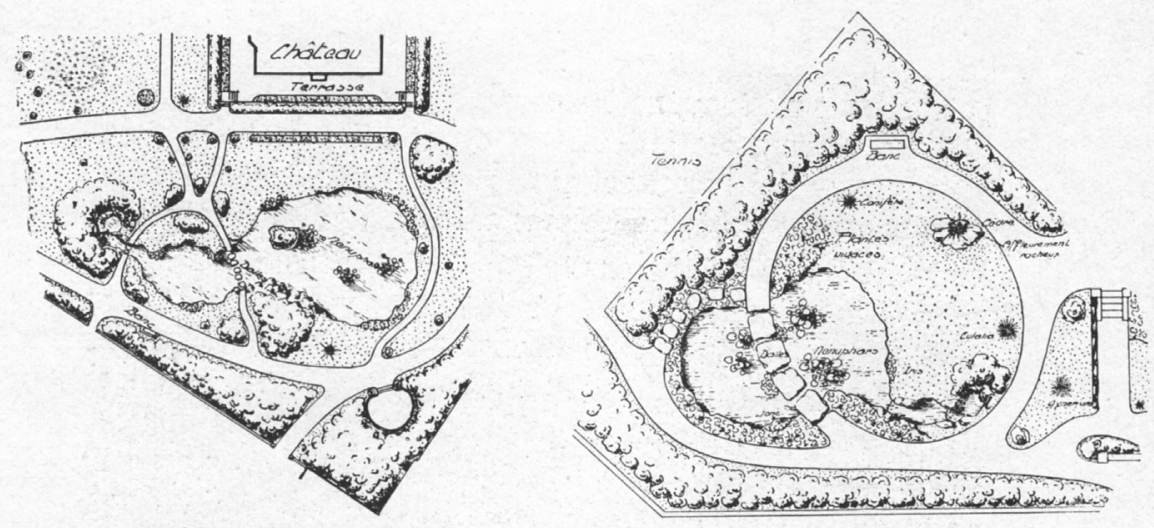

D'autres se contentent d'une grande humidité du sol, mais sans submersion, telles que: Equisetum hyemale, Iris sibirica, Iris Kaempferi, Ranonculus Lingua, Polygonum Bistorta, Arundo Donax, etc...

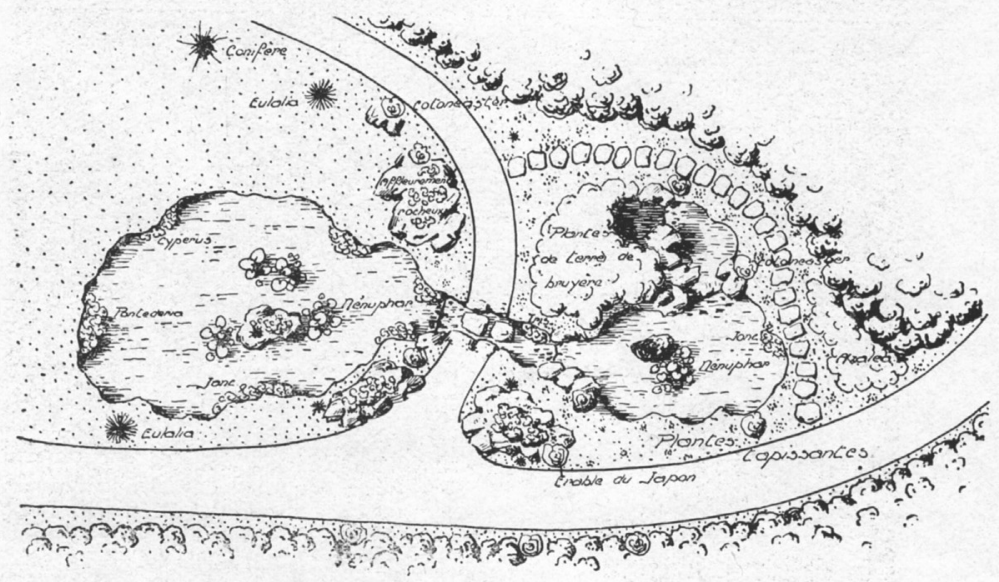

Elles serviront à garnir les bords de la pièce d'eau où la terre est maintenue humide par capillarité.

D'autres plantes aquatiques ont des feuilles flottantes telles que: Aponogeton distachyon, Ranunculus Aquatilis, Villarsia nympheoides et tous les superbes Nympheas ou Nénuphars qui sont les reines de la flore aquatique. Ces dernières doivent être plantées sous 40 à 50 centimètres d'épaisseur d'eau, de manière que jamais la gelée n'atteigne leurs racines. Il leur faut, pour prospérer, une couche de 30 à 40 centimètres de bonne terre de jardin, de préférence du gazon décomposé, mais sans aucun engrais animal.

Enfin, pour que les flores soient complètes dans votre bassin,

Fig. 13. Type plans for picturesque ponds. Source: Le Nouveau Jardin Pittoresque, 1924.

Loo and Zampa, 1994). This was also the case for Jean Canneel-Claes, a landscape architect who had studied under Van der Swaelmen at the ISAD (Imbert, 2009; Notteboom, 2009). Canneel promoted in the 1930s the 'functional garden', which he described as a garden that contributed to the 'physical and moral development of the individual and the collective', followed the 'form follows function' 


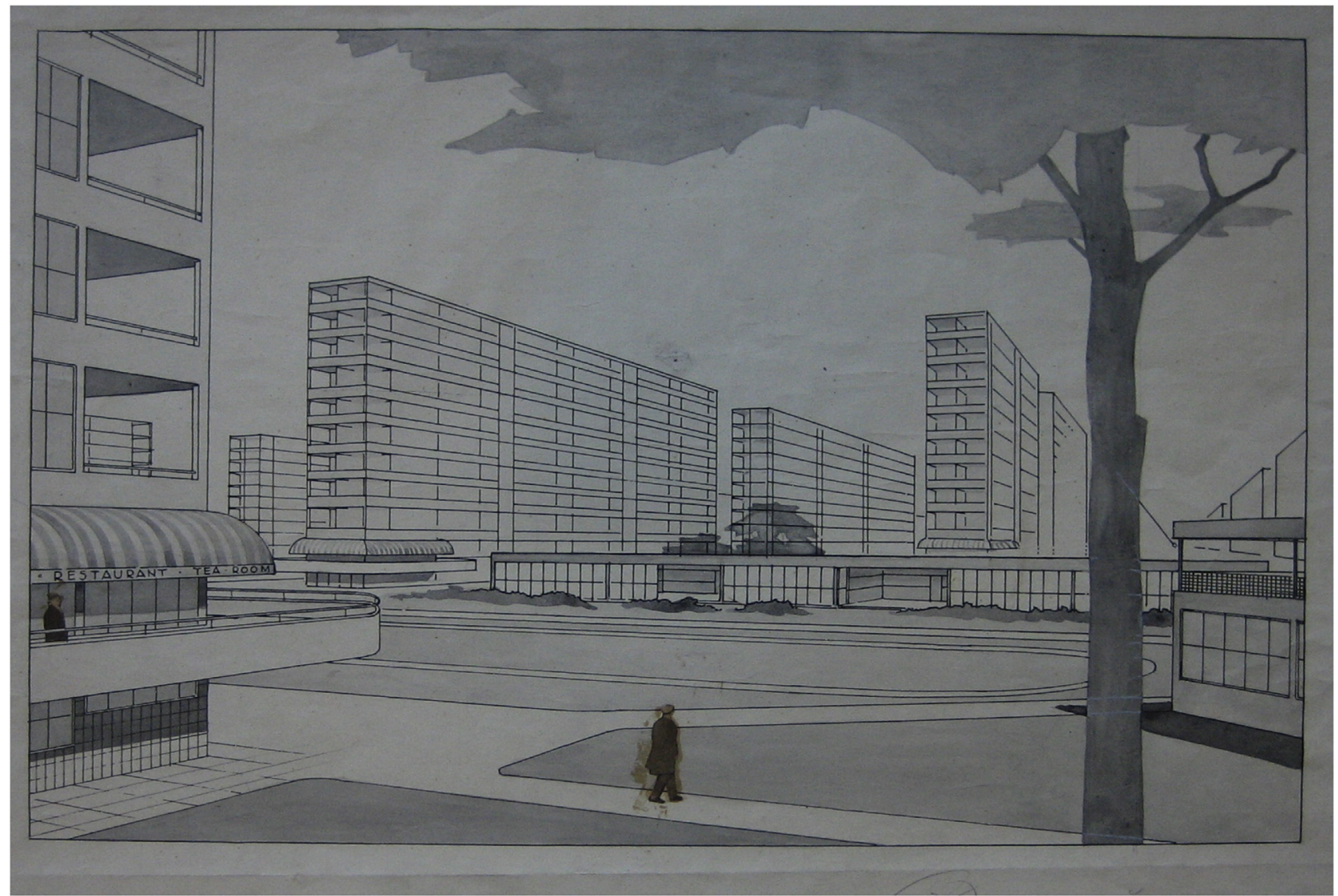

Fig. 14. Victor Bourgeois, Le Nouveau Bruxelles. Source: Archives d'Architecture Moderne.

principle, is not an imitation of nature and is based on geometric composition, although with respect to the site (Flouquet, 1938). Although the concept of the functional garden was a translation of modernist principles in architecture, his own house (designed by modernist architect Louis-Herman De Koninck) and garden constructed in 1931 did not break entirely with vernacular tradition and follows in fact a quite ambiguous blend of formal and functional paradigms. The formal language (geometric composition of hedges, rows of trees and flower beds), the indoor-outdoor continuity and the roof terrace were in tune with modernism. However the long, narrow plot, the presence of a kitchen garden and the program of a private single family house fenced-off from its surroundings combine modernist aesthetics with vernacular and even bourgeois dwelling practices. (Fig. 15)

\subsubsection{Gardens for the middle class}

In the course of the 1930s the contrast between the establishment and the avant-garde in garden and landscape design became more outspoken - at least on an aesthetic and rhetorical level. Already in 1925, on the occasion of the Paris Exposition des Arts Décoratifs of 1925, Jules Buyssens had fiercely rejected the 'cubism' and 'triangulism' of modern gardens designed by architects Georges Mallet-Stevens and Gabriel Guévrékian (Buyssens, 1926). It is no surprise then, that in the 1930s Buyssens and Canneel-Claes entered a polemic that was stimulated by the architectural press. When the functional garden was introduced in the architecture journal Bâtir, Canneel's vision was immediately confronted with that of Buyssens, in a discussion on the aesthetics and functional use of the garden (Canneel-Claes, 1933a; CanneelClaes, 1933b; Buyssens, 1933a; Buyssens, 1933b). (Fig. 16a, b) Canneel's own garden was presented as architectural, by stressing the 'green curtain' that continued the side facade into the garden, while Buyssens displayed a picturesque rock garden. Despite the formal difference of their designs, both Buyssens and Canneel aimed for the growing middle-class audience that had the budget for a garden. In another set of paired articles in Bâtir, in a 1933 theme issue on the middle-class house, both designers presented a garden for a terraced house on a typically Belgian long and narrow parcel (Imbert, 2009; Notteboom, 2009), under the heading of 'Jardins démocratiques' (Buyssens), and 'Un jardin complet pour une habitation moyenne' (Canneel) (Buyssens, 1933a; Buyssens, 1933b; Canneel-Claes, 1933a; Canneel-Claes, 1933b). Buyssens' garden had a symmetrical layout and consisted of a central path borderd by strips of lawn and borders with a half-round pergola at the end, a formal language that was borrowed from larger gardens and parks. Canneel on the contrary, created a spatial dynamic in the garden by an asymmetrical layout that shifted the path halfway the lot, and foreseeing a swing and sandpit, that could be transformed into a pond or a plant border. (Fig. 17) However, although Canneel's garden contrasted formally with the petit bourgeois garden of Buyssens, the social role of Canneel's garden was in fact quite similar in the sense that it was limited to the nuclear family and the individual. 'The 'functional' garden,' Canneel stated in an interview in 1934, 'is in the first place a practical garden, welcoming, conceived in the first place from the desire for relaxation in an intimate way (...), it offers a peaceful framework for contemporary Man, whose life is hectic. This is the social conception of the garden' (Flouquet, 1934). Comparing the gardens of Canneel and Buyssens reveals the ambiguity of the formal as well as social aspects of design, as it illuminates their differences but also reveals what they have in common. The middle-class gardens presented in Bâtir both didn't surpass the individual lot, spatially nor socially, 


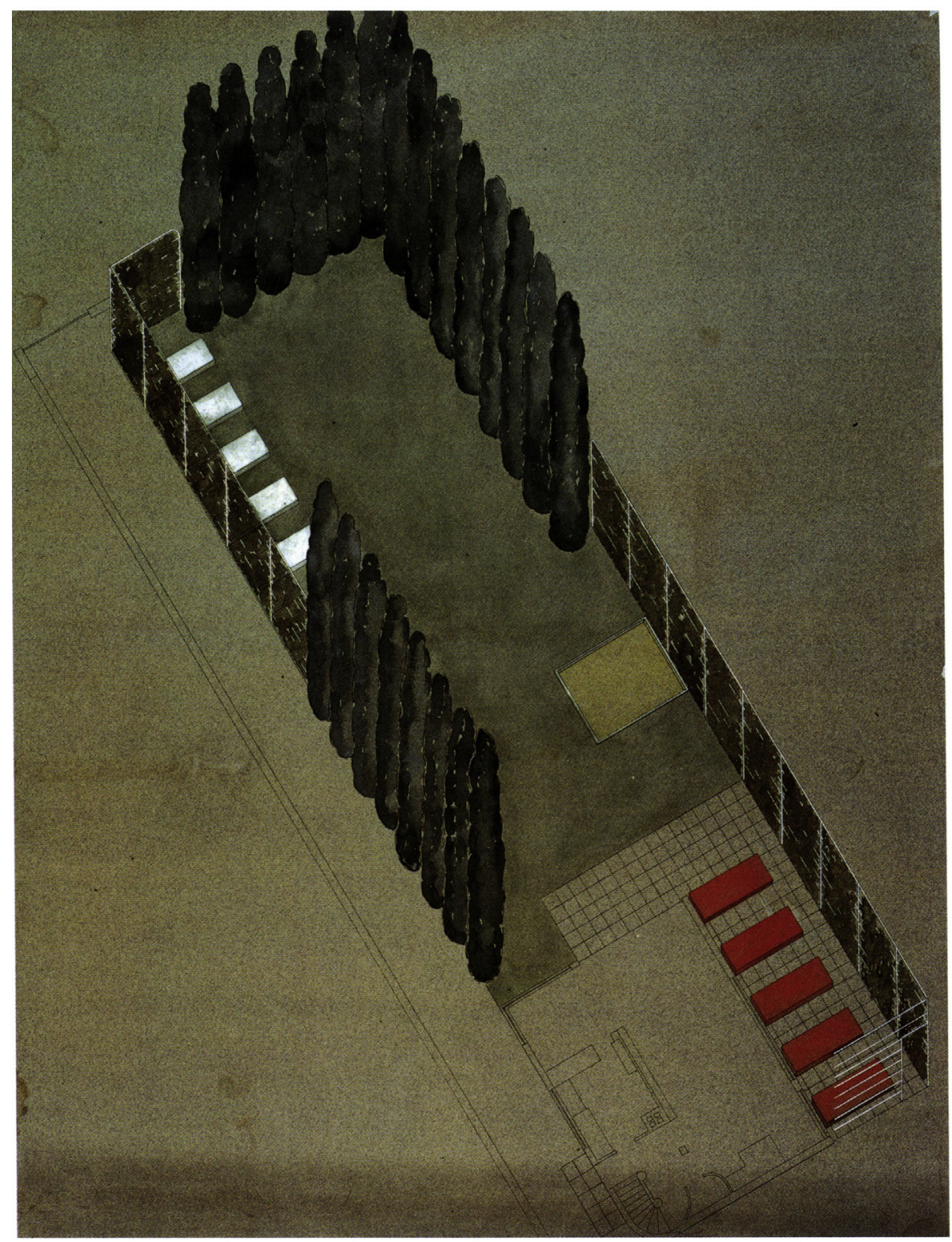

Fig. 15. Jean Canneel-Claes' own house and garden. Source: Archives d'Architecture Moderne, Brussels.

and in this sense the choice for a 'traditional' or 'modern' layout can be perceived as a question of style rather than ideology. Both were in the first place leisure gardens and a place to retreat from the world. They aimed at a growing public that disposed of sufficient time and budget to use the garden as a place of consumption rather than production, a type of garden that would dominate the residential landscape exponentially in the post-war welfare state (Van Herck and Avermaete, 2006).

\section{Discussion and conclusion}

\subsection{The role of the garden in social formation}

The four periods/themesfour periods/addressed in this paper give an idea of the complexities and ambiguities of the process of social formation by means of the garden. As Denis Cosgrove has argued, social formation is historically not only determined by the physcial landscape people live in, but also by symbolic landscapes (Cosgrove, 1998), depicted on paintings or photographs, or more recently distributed in manuals and journals. We can conclude that throughout the practice of gardening itself, as well as production and consumption of textual and visual discourses on gardens, social positioning works in different directions: lower classes imitate the higher classes, and higher classes distinguish themselves from the lower ones, and/or educate them, which leads to shifting and complex social identities over time, as is the case in dwelling culture (De Caigny, 2010). In the 1970s, sociologist Pierre Bourdieu wrote that taste is not an autonomous social given, but the result of social, cultural and economic capital that is exchanged (Bourdieu, 1979). Le Nouveau Jardin Pittoresque is an outstanding example of how physical gardens, and the way they are depicted and written about, play an important role in the acquisition of these forms of capital in several ways: what started out as an initiative to educate the workers' population, evolved into a device that helped its readers to stick to bourgeois symbols in a world in which the middle class was on the rise. How ambiguous and flexible the cultural meaning of gardens and green infrastructure can be, is illustrated by the different types of garden cities and villa allotments that are discussed in this paper: early twentieth-century green residential landscapes, such as Knokke-Zoute, Winterslag/Waterschei and 
Le Logis-Floréal, can function as places of exclusion, suppression and/or emancipation, however within a similar design language. The confrontation of Jean Canneel-Claes with Juls Buyssens illustrates a further shift in the role of the design language in social formation: as the middle class acquired social, economic and cultural capital during the interwar era, not only did 'picturesque' or 'modern' become styles to choose from, also socio-cultural dwelling practices became increasingly blurred.

As was touched upon throughout the paper, the role of the garden in processes of social formation very much depended on the role of the garden as a place of production and work (associated with the lower classes), or a place of consumption and leisure (indi-

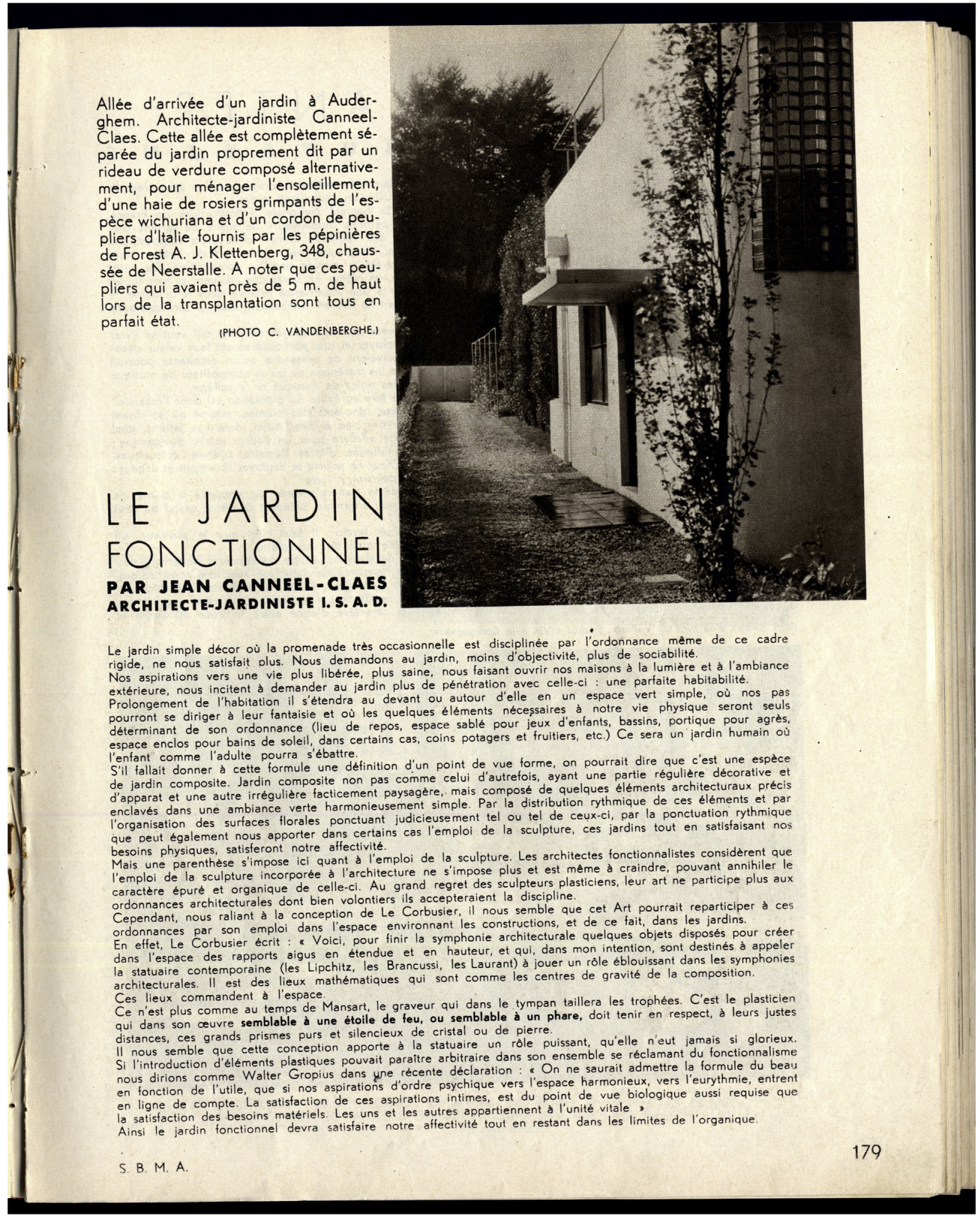

Fig. 16. a, b: Two visions on garden design in Bâtir: 'The functional garden’ by Jean Canneel-Claes and 'The art of planting', by Jules Buyssens. Source: Bâtir, 1933.

Please cite this article in press as: Notteboom, B., Residential landscapes-Garden design, urban planning and social formation in Belgium. Urban Forestry \& Urban Greening (2018), https://doi.org/10.1016/j.ufug.2017.02.013 


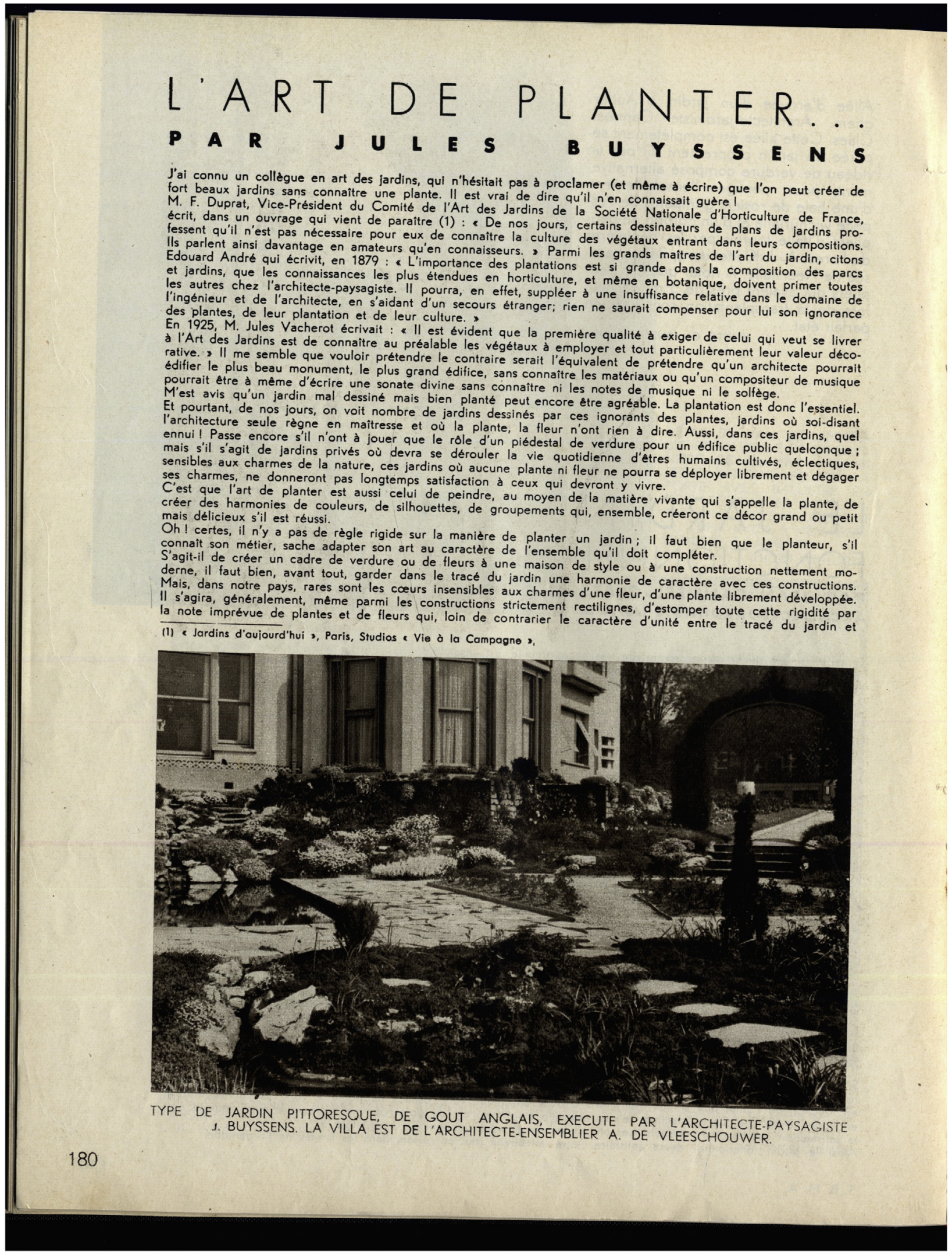

Fig. 16. (Continued)

cating a higher position on the social ladder). J.B. Jackson, one of the pioneers of cultural landscape studies, speaks in this context of 'gardens of the establishment' versus 'vernacular gardens' (Jackson,
1994). The vernacular house and garden produced during the gradual urbanization of the territory, were - and still are - by their lack of design a place of an outspoken individual freedom, a place for daily

Please cite this article in press as: Notteboom, B., Residential landscapes-Garden design, urban planning and social formation in Belgium. Urban Forestry \& Urban Greening (2018), https://doi.org/10.1016/j.ufug.2017.02.013 


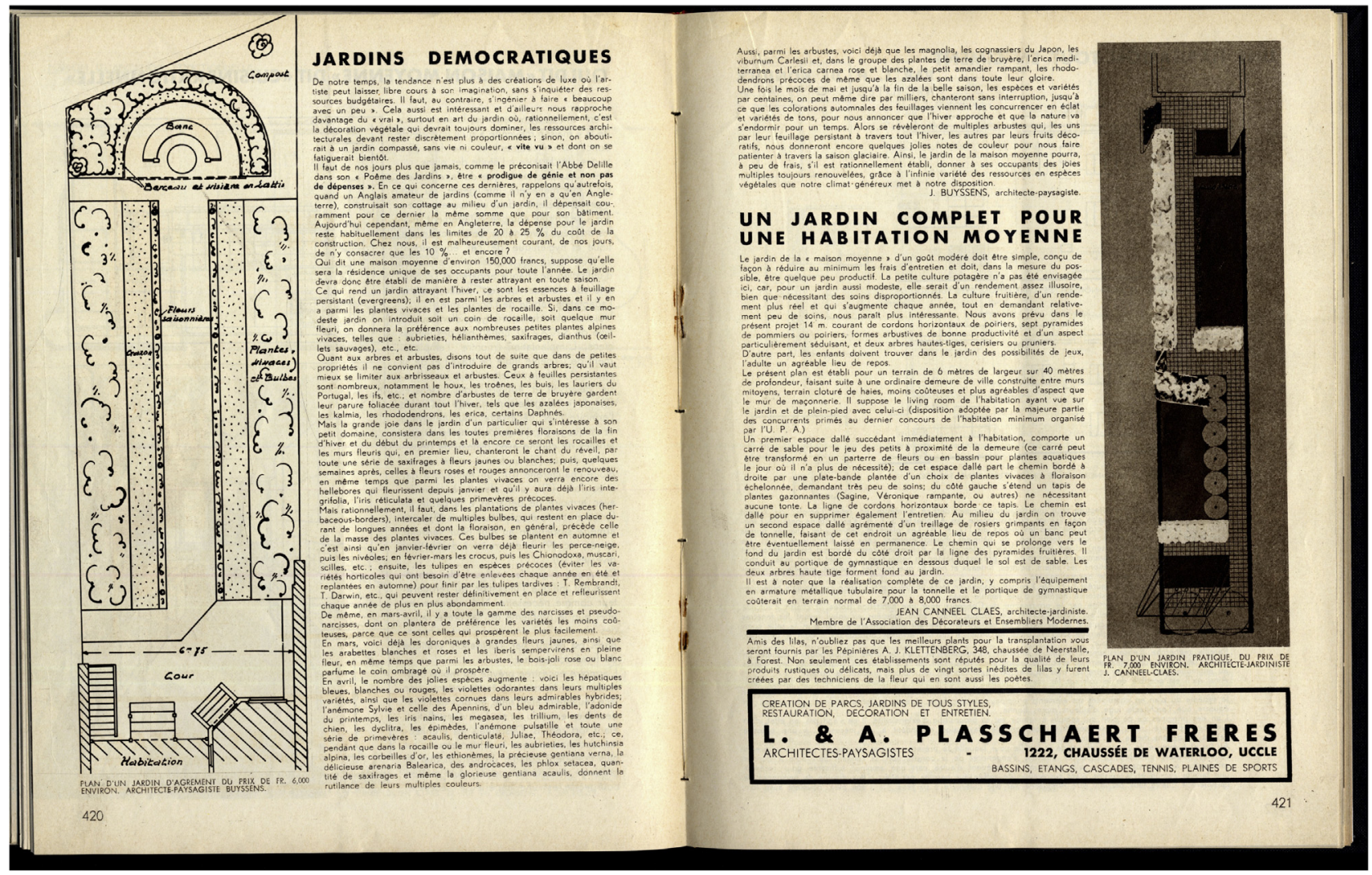

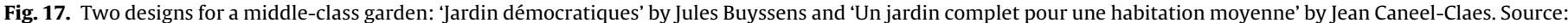
Batir, 1933.

life where one could escape from a dominant order (de Certeau, 1980), while the 'gard ens of the establishment' are subject to codes and restrictions. However, looking at the Belgian landscape today, one cannot help observing that the line is not always clear between vernacular and representational gardens. An interesting topic for further research, could be the question how, in socially diverse garden complexes, gardens of leisure are - historically and today - combined with a vernacular, productive use of the garden (e.g. using the difference between front and back yard), and how vernacular, multifunctional and constantly changing, private gardens can be inserted in a designed collective or public green framework that surpasses the individual lot.In order to set out strategic perspectives for the garden, addressing the question how to design the garden as a place where cultural identity can be shaped and maintained, we can learn a lot from history. Social distinction and imitation still play a role in the design of gardens today, and the cultural symbols that were developed in history still echo in our contemporary plant borders and lawns. Especially in the light of the increasing trend of returning to productive ways of gardeningfor example in the light of the discussion on the productive city and urban agriculture (Bell et al., 2016) urban, the discussion on 'vernacular' versus the 'establishment' garden is surprisingly timely.

\subsection{The relation between garden design and urban planning}

The cases analyzed in this paper expose the ambiguous relationship between the design of gardens and green spaces, processes of urbanization and the discipline of urban planning in Belgium. We outlined that gradual urbanization in Belgium was the result of a number of socio-economic and political decisions, which lead to a liberalization of both the labor and the land market. Bénédicte Grosjean called this process an 'urbanization without urbanism'
(Grosjean, 2010), with little or no intervention of designers. The supremacy of the private house and garden determines to a large extent the spatial configuration of the Belgian territory until today. Nevertheless, in the period studied in this paper the discipline of urban planning developed as an attempt correct this process of urbanization and to bring order in a territory that was becoming more and more chaotic. Garden and landscape design(ers) played an important role in new theories and practices that were developed during this period. The concept of sociobiology, that originated in the plant world, inspired Van der Swaelmen to plea for an urban planning that was rooted in topography and geography of the terrain. In the design of garden cities, the garden complex and the green infrastructure played a crucial role in creating a residential landscape that countered the fallacies of the modern, industrial city, while providing a density and a coherence that formed an alternative for vernacular urbanization. However, we also argued that the garden cities, as well as the grand interventioned proposed by CIAM, remained in reality isolated fragments in a dispersed landscape.

However, in order to deal with gardens in a strategic way today and in the future, these fragments in fact still offer a lot of potential and inspiration for futere developments. Garden cities, but also villa allotments as Knokke-Zoute remain models of how densification and the creation of a qualitative open space can take place. (De Meulder et al., 1999). Because of their ingenious interaction between public, collective and private green spaces, these centuryold residential enclaves still offer a far more aesthetic and social qualitiy than the post World War II suburban developments, that are now in need of a massive renovation and reconceptualization. Recent research has also pointed out that also residential gardens in a context of spatial dispersal, such as ribbon developments, open up new ways of creating ecological networks and offering ecosystem 
services, even in a context of private development (Dewaelheyns et al., 2011). I stated in the introduction that Belgian garden and landscape designers, historically and today are frustrated by their inability to leap the garden fence. However, because of its spatial and social complexity and ambiguity, what the Belgian residential landscape lacks in coherence, is perhaps compensated by the fine-mazed, 'messy' and unplanned juxtaposition of planned and unplanned public, collective and private space. What landscape designers and urban planners alike should aim at, in my opinion, is not necessarily the grand gesture, but optimization of green spaces both within and outside of the garden fence, and establishing smart relations between both.

\section{References}

Anon, 1914a. Programme général des matières du bulletin. Le Nouveau Jardin Pittoresque, 56-57.

Anon, 1914b. Liste des Membres de l'Association. Le Nouveau Jardin Pittoresque $1-2,74-76$.

Bell, Simon, Fox-Kämper, Runrid, Keshavarz, Nazila, Benson, Mary, Caputo, Silvio, Noori, Susan, Voigt, Annette (Eds.), 2016. Routledge.

Bodson, H., De Bruyne, F., De Ridder, J., De Ligne, Hoste, H., Thirion, C., Patris, C., Van Averbeke, E., Van der Swaelmen, L., Van de Voorde, O., Verwilghen, R. 1919. S. U. B. manifeste de la société des urbanistes belges. La Cité 3, 37-40.

Bourdieu, P., 1979. La Distinction. Critique Sociale Du Jugement, Les Éditions de Minuit Paris.

Braem, R., 1968. Het Lelijkste Land Ter Wereld. Davidsfonds, Leuven.

Buyssens, J., 1925. Nécrologies. Jean Massart. Le Nouveau Jardin Pittoresque, Autumn, 54-56.

Buyssens, J., 1926. Tribune Libre. Evolution. Le Nouveau Jardin Pittoresque, Summer, 67-68.

Buyssens, J., 1933. L'art de planter. Bâtir, 5, 180.

Buyssens, J., 1933. Jardins démocratiqueBâtir, 1933s. Bâtir, 1933, 421-422.

Canneel-Claes, J., 1933. Le jardin fonctionnel. Bâtir, 5, 1933, 179.

Canneel-Claes, J., 1933 Un jardin complet pour une habitation moyenne. Bâtir, $1933,421$.

Clapson, M., 2003. Suburban century. In: Social Change and Urban Growth in England and the USA. Berg, Oxford/New York.

Colomina, B., 2002. The split wall. Domestic voyeurism. In: Colomina, B., Bloomer, J., Burgin, V., Grosz, E. (Eds.), Sexuality and Space. Princeton University Princeton, pp. $72-80$

Conan, M., 1999. From vernacular gardens to a social anthropology of gardening. In: Conan, M. (Ed.), Perspectives on Garden Histories. Dumbarton Oaks, Washington, DC, pp. 181-205.

Cosgrove Denis, E., 1998. Social Formation and Symbolic Landscape. University of Wisconsin Press Madison (Wis).

De Block, G., Polasky, J., 2011. Light railways and the rural-urban continuum: technology, space and society in late nineteenth-century Belgium. J. Hist. Geogr. 37 (3), 312-328, http://dx.doi.org/10.1016/j.jhg.2011.01.003.

De Caigny, S., 2010. Bouwen Aan Een Nieuwe Thuis: Wooncultuur in Vlaanderen Tijdens Het Interbellum. Leuven University Press, Leuven.

De Decker, P., 2011. A garden of Eden? The promotion of the single-family house with a garden in Belgium before the Second World War. In: Dewaelheyns, V., Bomans, K., Gulinck, H. (Eds.), The Powerful Garden. Emerging Views on the Garden Complex. Garant, Antwerp/Apeldoorn.

De Meulder, B., Schreurs, J., Cock, A., Notteboom, B., 1999. Patching up the belgian urban landscape. Oase 52, 78-113.

DeBlock, G., 2011. Engineering the Territory. Technology, Space and Society in 19th and 20th Century Belgium. Ph.D. Thesis. Catholic Univeristy of Leuven, Leuven.

Dewaelheyns, V., Bomans, K., Gulinck, H. (Eds.), 2011. Emerging Views on the Garden Complex. Garant, Antwerp/Apeldoorn.

Fishman, R., 1989. Bourgeois Utopias. The Rise and Fall of Suburbia. Basic books, New York.

Flouquet, P.-L., 1934. La leçon au fond du jardin. Le jardin fonctionnel. Interview de l'architecte jardiniste Jean Canneel-Claes. Batir 24, 927.

Flouquet, P.-L., 1938. L’Association internationale des architectes de jardins modernistes. Bâtir 64, 130-133.

Flyvbjerg, B., 2006. Five Misunderstandings About Case-Study Research. Qual. Inq. 12 (2), 219-245, http://dx.doi.org/10.1177/1077800405284363.

Grosjean, B., 2010. Urbanisation Sans Urbanisme. Une Histoire De La Ville Diffuse. Wavre, Mardaga.

Haney, D.H., 2010. When Modern Was Green. Life and Work of Landscape Architect Leberecht Migge. Routledge, Abingdon/New York.

Hayden, D., 2004. Building Suburbia. Green Fields and Urban Growth. Vintage books, New York.
Imbert, D., 2009. Between Garden and City: Jean Canneel-Claes and Landscape Modernism. University of Pittsburgh Press, Pittsburgh.

Jackson, J.B. (Ed.), 1994. Yale University Press, New Haven/London, pp. 118-133.

Karnau, O., 1996. Hermann Jozef Stübben. Städtebau 1876-1930, Vieweg Braunschweig.

Krabbe, W.R., 2001. Die lebensreformbewegung. In: Buchholz, K., Latocha, R., Peckmann, H., Wolbert, K. (Eds.), Die Lebensreform. Entwürfe Zur Neugestaltung Von Leben Und Kunst Um 1900. Häusser, Darmstadt.

Lauwers, H., Coppens, T., 2012. 's Lands natuurschoon. 50 jaar wet op de stedenbouw, VRP, Antwerp.

Loeckx, A., Heynen, H., Stynen, H., De Meulder, B., 1991. Geschiedenis Op Zoek Naar Waardig Vervolg: Studie Van De Mijnnederzettingen in Waterschei Winterslag En Eisden Koning Boudewijnstichting Brussel.

Massart, J., Vandervelde, É., 1895. Parasitism, Organic and Social. Swan Sonnenschein \& Co, London.

Massart, J., 1910. Esquisse De La géographie Botanique De La Belgique. Lamertin, Brussels.

Mitchell, W.J.T., 2002. Landscape and Power. University of Chicago Press, Chicago.

Notteboom, B., Peleman, D., 2012. Narratives of loss and order and imaging the belgian landscape 1890-1945. CLCWEb 4 (3) (Article 11, n.p).

Notteboom, B., 2009. 'Ouvrons Les Yeux!' Stedenbouw En Beeldvorming Van Het Landschap in België 1890-1940. Ph.D. Thesis. Ghent University, Ghent.

Notteboom, B., 2012. Le nouveau jardin pittoresque ethics, aesthetics and garden design in Belgium (1913-1940). J. Landscape Archit. 7 (2), 58-63.

Peleman, D., 1962. 'Les Hommes De La Route'. Engineering the Urban Society of the Modern Road in Belgium, 1889-1962. Ph.D. Thesis. Ghent University, Ghent, pp. 2013.

Rens, G., 1925. La signification morale des Cités-Jardins, 7 Arts, 4(1).

Ryckewaert, M., 2011. Building the Economic Backbone of the Belgian Welfare State: Infrastructure, Planning and Architecture 1945-1973, 010, Rotterdam.

Segers, Y., Van Molle, L., 2007. Volkstuinen. Een Geschiedenis. Davidsfonds, Leuven.

Smets, M., Buls, C., 1995. Les Principes De l'art Urbain. Mardaga, Liège.

Smets, M., 1930. De Ontwikkeling Van De Tuinwijkgedachte in België. Een Overzicht Van De Belgische Volkswoningbouw in De Periode Van 1830 Tot 1930. Mardaga, Brussels, pp. 1977.

Smets, M., 1985. Resurgam. De Belgische Wederopbouw Na 1914. Gemeentekrediet van België Brussels.

Strauven, I., 2015. Victor Bourgeois (1897-1962). Radicaliteit En Pragmatisme. Moderniteit En Traditie. A\&D, Mechelen.

Stynen, H., 1979. Stedebouw En Gemeenschap. Louis Van Der Swaelmen (1883-1929), Bezieler Van De Moderne Beweging in België. Mardaga, Brussels.

Stynen, A., 2010. Proeftuinen Van Burgerlijkheid: Stadsnatuur in Negentiende-eeuws België. Ph.D. Thesis. Catholic University of Leuven, Leuven.

Treib, M. (Ed.), 2002. University of Pennsylvania press, Philadelphia.

Tritsmans, B., 2014. Waardevolle Bijkomstigheden: Stedelijk Groen in Beleid En Beleving. PhD. Thesis. University of Antwerp, Antwerp.

Uyttenhove, P., 2003. Stedenbouw. In: Van Loo, A., Strauven, F. (Eds.), Repertorium Van De Architectuur in België Van 1830 Tot Heden. Mercatorfonds, Antwerpen, pp. 398-405.

Van Acker, M., 2014. From Flux to Frame. Designing Infrastructure and Shaping Urbanization in Belgium. Leuven University Press, Leuven.

Van Billoen, A., 1913. Le Nouveau Jardin Pittoresque. Rénovation. Vulgarisation. In: Le Nouveau Jardin Pittoresque. Association Nationale pour la Rénovation dans l'Art des Jardins. Son Programme, Le Nouveau Jardin Pittoreque, Brussels.

Van Damme, S., 2013. Landschapsontwerp in Vlaanderen: Landschap Als Naratief En Integrerend Medium in De Ruimtelijke Ontwerppraktijk. Garant, Antwerp.

Van Herck, K., Avermaete, T. (Eds.), 2006. Woningbouw En Wooncultuur in Vlaanderen, 1948-1873. 010/VAi/CVAa, Rotterdam, Antwerp.

Van Loo, A., Zampa, F., 1994. Stedenbouw en architectuur. In: Spriet, W., Gobyn, R. (Eds.), De Jaren '30 in België. De Massa in Verleiding. ASLK, Brussel, pp. 196-217.

Van der Swaelmen, L., 1913. L'Art des Jardins et le Nouveau Jardin Pittoresque. Tekhné 10, Appendix, 3.

Van der Swaelmen L.,1913. Du Respect des Sites et de l'Aménagement de leurs abords. In: Rapport Congrès d'Horticulture - Gand 1913, Gaston Bonnet, Brussel.

Van der Swaelmen L., 1916. Préliminaires d'Art Civique, mis en relation avec le cas clinique de la Belgique, A.W. Sijthoff, Leiden.

Van der Swaelmen, L., 1916b. Twee voordrachten over moderne tuinkunst. Ile deel. Architectura 16, 122-126.

Van der Swaelmen, L., 1925. Cité-Jardin Floréal, L'Habitation à Bon Marché, 5.

Verwilghen, R., 1919. L’Urbanisme dans les différents pays. La Cité 6, 101.

Vinck, E., 1939. Inleiding/Editorial. Urbs Nova 1, 2-5.

de Certeau, M., 1980. L'invention Du Quotidien I. Arts De Faire. Union générale d'éditions, Paris.

Wolschke-Bulmahn, J., 2004. All of Germany a garden? In: Mauch, C. (Ed.), Nature in German History. Berghahn Books, New York/Oxford, pp. 74-92. 